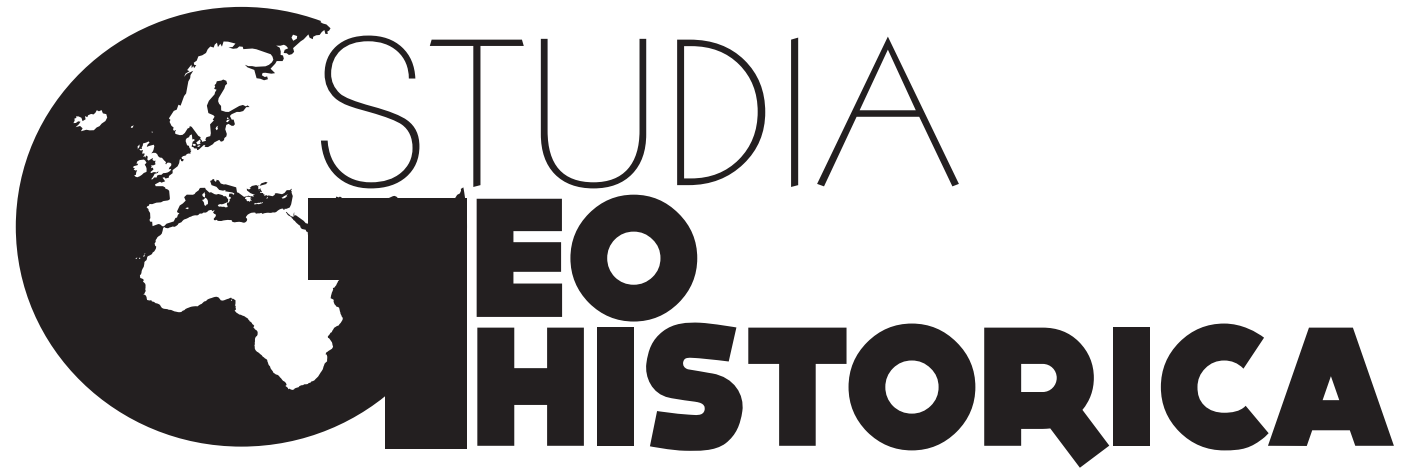

NR 04|2016 ROCZNIK HISTORYCZNO-GEOGRAFICZNY

Fundacja Centrum GeoHistorii • Instytut Geodezji i Kartografii • Instytut Historii KUL

Instytut Historii i Stosunków Międzynarodowych US • Zespół Historii Kartografii przy Instytucie Historii Nauki PAN Biblioteka Główna Uniwersytetu Szczecińskiego 


\section{STUDIA GEOHISTORICA. Rocznik historyczno-geograficzny}

\section{Redakcja}

Bogumił Szady (redaktor naczelny), Beata Konopska, Radosław Skrycki, Tomasz Związek (sekretarz redakcji), Tomasz Panecki

\section{Redakcja językowa i korekta}

Konrad Byzdra

\section{Tłumaczenia}

autorzy, Julia Szołtysek

\section{Rada Naukowa}

Zdzisław Budzyński (Rzeszów), Andrzej Janeczek (Warszawa), Tomasz Jurek (Poznań), Keith Lilley (Belfast/Wielka Brytania), Andrew Pernal (Brandon/Kanada), Tadeusz Siwek (Ostrawa/Czechy), Rostysław Sossa (Kijów/Ukraina), Grzegorz Strauchold (Wrocław), Robert Šimůnek (Praga/Czechy)

\section{Recenzenci tomu 4}

Wojciech Chudziak, Martyna Deszczyńska, Zbigniew Górczak, Maria Jankowska, Iwona Jażdżewska, Andrzej Klonder, Anna Kołodziejczyk, Andrzej Kopiczko, Małgorzata Elżbieta Kowalczyk, Adam Kozak, Joanna Kumor-Mielnik, Mieczysław Kunz, Dariusz Lorek, Wojciech Mielewczyk, Grzegorz Myśliwski, Wiesław Nowosad, Piotr Pabjanek, Marek Radoch,

Małgorzata Rutkiewicz-Hanczewska, Francesco Somaini, Péter Szabó, Piotr Werner, Filip Wolański

\section{Redakcja map}

autorzy, Tomasz Panecki

\section{Adres Redakcji}

Fundacja Centrum GeoHistorii

Redakcja Studia Geohistorica

05-082 Stare Babice, ul. Gen. Tadeusza Kutrzeby 4

\section{Strona internetowa}

studiageohistorica.pl

Wersja drukowana (papierowa) jest wersją pierwotną rocznika Studia Geohistorica

\section{Współwydawcy rocznika}

Biblioteka Główna Uniwersytetu Szczecińskiego, Fundacja Centrum GeoHistorii, Instytut Geodezji i Kartografiii, Instytut Historii Katolickiego Uniwersytetu Lubelskiego Jana Pawła II, Instytut Historii i Stosunków Międzynarodowych Uniwersytetu Szczecińskiego, Zespół Historii Kartografii przy Instytucie Historii Nauki PAN

Rocznik wydawany pod patronatem Komisji Geografii Historycznej przy Polskim Towarzystwie Historycznym Projekt okładki: Jacek Młodożeniec Ilustracja na okładce: Kalisz - Plan miasta i przyległej okolicy autorstwa Ludwiga von Bröckera z 1802 r. Skład i łamanie: Artur Hamryszczak

(C) Copyright by Fundacja Centrum GeoHistorii

ISSN 2300-2875

Nakład 100 egz.

Warszawa 2016 


\section{Spis treści • Contents}

\section{Tradycje geografi historycznej • Traditions of historical geography}

\section{Ludomir Sawicki}

Geografia a krajoznawstwo

(uwagi wstępne Beata Konopska, opracowanie Beata Konopska)

\section{Stanisław Herbst}

Prace nad „Atlasem historycznym Polski”

(uwagi wstępne Henryk Rutkowski, opracowanie Henryk Rutkowski).

\section{Artykuty $\bullet$ Articles and theses}

\section{Elżbieta Kowalczyk-Heyman}

Czym były mazowieckie "płozy"? (uwagi wstępne)

What were the Masovian "płozy"? (Preliminary Remarks)

\section{Robert Klimek}

Ślady średniowiecznej granicy Warmii między Reszlem a Świętą Lipką

Traces of the Medieval Border of Warmia between Reszl and Święta Lipka

\section{Ewa Ziółek}

Relacja Grzegorza Piramowicza o osuszaniu Bagien Pontyjskich za pontyfikatu Piusa VI

Grzegorz Piramowicz's Account of Draining the Pontian Marshes during

the Pontificate of Pope Pius VI

\section{Krzysztof Boroda}

Wpływy z czopowego jako wskaźnik lokalnego zróżnicowania poziomu produkcji

piwa pełnego w miastach Królestwa Polskiego w latach 60. XVI w.

Income from Czopowe as an Indicator of Regional Diversity of Full Beer

Production in the Cities of the Polish Crown in the 1560s

\section{Xavier Rochel}

The End of Gaps and Heathlands in French National Forests, $19^{\text {th }}$ Century.

A Case Study Based on Forest Management Plans

Zanik polan i wrzosowisk we francuskich lasach państwowych w XIX w.

Studium przypadku na podstawie planów zarządzania lasami

\section{Tomasz Figlus}

Typy morfogenetyczne wsi w środkowej Polsce

Morphogenetic Types of Rural Settlements in Central Poland. 
Tomasz Babczyński, Tomasz Kubik, Roman Ptak, Grzegorz Strauchold GIS as a Tool to Analyze the History of Silesia and the Changes in its Political (and Cultural) Geography GIS jako narzędzie do analizy historii Śląska oraz zmian w jego geografii politycznej i kulturowej..

\section{Mateusz Zawadzki}

"Tabella miast, wsi i osad Królestwa Polskiego" jako źródło do badań nad strukturą parafialną województwa lubelskiego

The "Tabella of Towns, Villages and Settlements of the Kingdom of Poland" as the Source for Research into the Parochial Structure of the Lublin Voivodeship

Anna Paulina Orłowska, Bartosz Nowożycki, Grzegorz Pac Handel wołami na terenie Wielkopolski i Śląska w świetle szesnastowiecznego spisu jarmarków i komór celnych The Trade in Oxen on the Territory of the Greater Poland and Silesia in the Light of the $16^{\text {th }}$ Century Description of Annual Fairs and Toll Houses

\section{Recenzje i omówienia $・$ Reviews and discussions}

Historical Atlas of Poland in the $2^{\text {nd }}$ half of the $16^{\text {th }}$ Century: Voivodeships of Cracow, Sandomierz, Lublin, Sieradz, Łęczyca, Rawa, Płock and Mazovia, ed. by Marek Słoń; transl. by Agata Staszewska; Martha A. Brożyna, Peter Lang Edition, Frankfurt am Main 1973-[2014], 4 volumes, XXIX + 1597 pp., illustrations, 27 folded maps

(Alexei Frolov)

Magdolna Szilágyi: On the Road: The History and Archaeology of Medieval Communication Networks in East-Central Europe, Budapest 2014

(Archeolingua Series Minor, 35),

Ss. 254, 89 il. (w tym 30 map i 4 plany miast)

(Ewelina Siemianowska).

The World in a Mirror, Word Maps from the Middle Ages to the Present Day, ed. Jan Parmentier, Museum aan de Stroom, Antwerp 2015, ss. 192, il. $150+25$ (Lucyna Szaniawska)

Kartografia morska i krain nadmorskich, red. R. Skrycki, Instytut Historii

i Stosunków Międzynarodowych Uniwersytetu Szczecińskiego,

Zespół Historii Kartografii Instytutu Historii Nauki PAN, Szczecin 2014;

$24 \times 17$ cm, ss. 204, 54 ryc., 4 tab.

(Jan Rutkowski) 
Алексей А. Фролов, Нина В. Пиотух: Исторический атлас Деревской пятины Новгородской земли (по писцовым книгам письма 1495-1496 годов). В 3 томах: Москва-Санкт-Петербург, Альянс-Архео, 2008.

Т. 1: Исследование и таблицы, ss. 368;

Т. 2: Атлас и справочные материалы, ss. 272;

T. 3: Уездные планы последней четверти XVIII века, ss. 266

(Rostysław Sossa).

Nazwy miejscowe Polski. Historia. Pochodzenie. Zmiany, t. 10-12 (Ra-Rż), red. K. Rymut, B. Czopek-Kopciuch, U. Bijak, [autorzy haseł: U. Bijak, E. Borysiak, J. Chłądzyńska, B. Czopek-Kopciuch, P. Dudek, A. Galasińska, W. Makula-Kosek, I. Nobis, R. Przybytek, P. Swoboda, U. Wójcik, K. Zawodzińska-Bukowiec, Z. Zierhoffer], Polska Akademia Nauk. Instytut Języka Polskiego, Kraków 2015, ss. 160 (t. 10), 146 (t. 11), 168 (t. 12) (Ewa Oronowicz-Kida).

Kit Mayers: The First English Explorer. The Life of Anthony Jenkinson (1529-1611) and his Adventures on Route to the Orient, Devon 2015, ss. 366

(Krystyna Szykuła).

\section{Komunikaty $i$ sprawozdania $\bullet$ Communiques and reports}

Konferencja „Przestrzenne aspekty historycznych badań demograficznych, społecznych i gospodarczych (do 1945 r.)" - Pobierowo, 21-23 października 2015 r.

(Michał Gochna)

„European Social Science History Conference” - Walencja (Hiszpania),

30 marca-2 kwietnia $2016 \mathrm{r}$.

(Michał Gochna)

Zebranie naukowe polskiej sekcji European Society for Environmental History - Warszawa, 16 stycznia $2016 \mathrm{r}$.

(Piotr Guzowski)

„Mapa jako narracja interpretacyjna”. XXIX Ogólnopolska Konferencja Historyków Kartografii - Wrocław, 24-26 września $2015 \mathrm{r}$.

(Jerzy Ostrowski)

Sprawozdanie z konferencji „Województwo poznańskie w XVI w.” - Kościan, 1 lipca 2015 r.

(Michał Stomski).

Sprawozdanie z konferencji „Geografia historyczna. Wyzwania przyszłości” - Łódź, 11-12 czerwca 2015 r.

(Magdalena Deptuła). 204 
Spis treśsi

Pro memoria

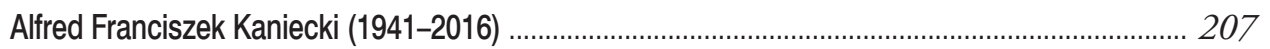

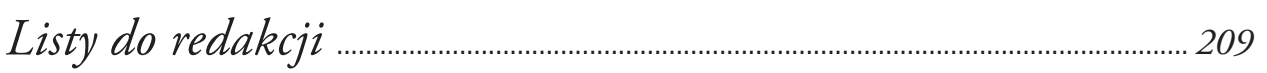

Informacja dla autorów • Guidelines for Authors .................................................... 210 


\title{
GIS as a Tool to Analyze the History of Silesia and the Changes in its Political (and Cultural) Geography
}

\author{
Tomasz Babczyński, Tomasz Kubik, Roman Ptak, Grzegorz Strauchold
}

\section{Introduction}

The area which was shaped as the geopolitical and regional concept of Silesia for the last millennium was subordinated to changing state and political configurations. The beginnings of these lands are not easy to define, and it is difficult to confirm that the territories belonged to the so-called Samo's Empire ( $7^{\text {th }}$ c.). It is simpler to present the hypothesis regarding their affiliation with Great Moravia ( $9^{\text {th }}$ c.). In later centuries, Silesia was a part of such countries as the Czech state, Poland, the Habsburg Monarchy, Prussia and Germany - all which is confirmed in historical sources.

When conducting a historical analysis of the processes and phenomena that took place in Silesia, besides the cause-and-effect context it is also worth considering their temporal and spatial dimensions. Such a reference allows one not only to better comprehend the course of events but also to analyze and describe them by using an appropriate tool. For historians, a source of knowledge are documents, written relations or found artifacts and their localizations. Maps should also be added to this set, as they constitute an invaluable aid in research on processes and phenomena that either refer to space or influence it, i.e. changes in national borders or administrative units, in the territorial division in general, the expansion of economic regions, and the localization and migration of ethnic groups.

Apart from these documentary and illustrational roles (separately or as a part of atlases), the map played an important referential role in history. It has always been an indispensable tool in carrying out significant tasks in the field of public administration, industrial activity, education, defense policy, etc. At the beginning, information displayed in maps was symbolic in nature. However, together with the development of tools and techniques in geodesy and cartography, this information became more and more precise, and the methods of mapping objects and spatial phenomena represented current needs. Thus maps were created with various content which was presented in different ways, proper to particular schools of cartography or particular domains.

For history researchers, old maps are an extraordinarily valuable source of information. However, their usage brings about technical and semantic problems. Apart from problems related to matching old maps to contemporary frames of geographical references, which is an indispensable step in order to perform comparative analyses, a correct interpretation of their elements is also quite problematic. Due to the cultural and linguistic diversity in Silesia, a characteristic of maps that refer to this same area are discrepancies in names, symbols, and other factors depending on individual traits in the edition.

When looking at old maps and their accompanying historical sources from the point of view of analyses, one may also wonder if any methods exist, except for library cataloguing, that would enable integration of these different products. Are there any methods that allow to associate the sources intelligently, not only on the basis of their categories and key words? Can we use such filters as spatial, temporal, or thematic ones which would enable an automatic or semi-automatic association of the sources according to the type of their contents?

These questions are crucial, since the analyzed sources may be treated not only as information sources but also as a knowledge base that allows to put forward and verify new hypotheses, i.e. something to be investigated. Here, subsequent questions arise: How do we extract data from 
our resources and what verification techniques do we use? For example, how do we extract the names of towns and villages from old maps, how do we determine the localization of objects or transportation routes? Moreover, how do we present the results of such analyses, i.e. how do we present historical phenomena in spatialtemporal terms?

The rise in information technology (including technologies that enable spatial data processing, making data available on the Internet, and associating sources by means of the Semantic Web) provides opportunities to find answers to the questions above. It has also brought a remarkable change in the systems of values, as information has become a product and politicians have raised the issue of building an information society.

For many years information systems have functioned that use maps as referential material, as the foundation to present various contents to which one may refer by creating added values. However, after a closer investigation it appears that it is not the very map that provides the referential material but the data on the basis of which it was created. It is sets of objects together with their geometry, descriptive attributes and metadata that play the role of the geodetic control network, in reference to which ready-made products in the form of maps are constructed.

The above-mentioned systems have evolved, going through consecutive stages of development. First, these were applications that functioned locally, then they were complex applications that used databases and communicated within the computer network. Advanced systems that support spatial data processing were named GIS (Geographic Information System). Next, users were provided with the opportunity to share spatial data via web services. Thus a spatial data infrastructure (SDI) was developed. When the above-mentioned systems became available through web browsers, they were named webGIS.

The construction of spatial data resources has always been an issue of great importance for public administration, businesses, and com- munities. In the domain of administration, a crucial moment was the issuing of the directive INSPIRE (Infrastructure for Spatial Information in Europe), which focuses on sharing spatial data between EU member states and which gave the formal bases for the creation of a spatial information infrastructure. To ensure compatibility and usability in the transboundary context the Directive requires that common Implementing Rules (IR) are adopted in a number of specific areas (Metadata, Data Specifications, Network Services, Data and Service Sharing and Monitoring and Reporting). These IRs are adopted as Commission Regulations/Decisions ${ }^{1}$.

The Directive addresses 34 spatial data themes needed for environmental applications. Among the INSPIRE themes many share commons with area of interest of historians. But the Directive is strictly related to the present (monitoring) and future (planning). The past, i.e. problems of processing historical resources from the pre-computer era, are quite weakly accentuated. Fortunately the INSPIRE standards can be adopted also to cover also such use cases.

Despite the implementation of different systems and software, the following questions are still valid: How does one integrate historical sources that refer to space? How does one obtain and use them? How does one present the findings of historical investigations that go beyond the opportunities provided by classic atlases.

In this paper, most of the above-mentioned problems are elaborated upon. First, the history of Silesia is discussed and illustrated with maps that have been created contemporarily (fig. 1-3). Next, some methods are presented of obtaining historical knowledge, the issue of data processing and the integration of resources. Old maps (fig. 9-11) and other source materials (fig. 8) were used as data sources. Afterwards, some aspects are discussed of dynamic data visualization and software tools used in data publication. Hence we present how collected data may be made available through the interfaces of network services, such as map services and gazetteers (fig. 14).

${ }^{1}$ http://inspire.ec.europa.eu/index.cfm/pageid/3, access: 24 July 2016. 


\section{Profile of Silesia}

\subsection{Overview of the history of Silesia}

The territories currently defined as Silesia were probably under the control of a Slavic state, the so-called Great Moravia, in the $9^{\text {th }} \mathrm{c}$. After it was defeated at the beginning of the $10^{\text {th }} \mathrm{c}$. by the nomadic tribes of the Magyars, the area was taken over by the Duchy of Bohemia, a successive Slavic state. However, ca. 990, Duke of the Polans, Mieszko I, waged a victorious war against the Czechs and seized the Silesian lands, which is presented in figure 1 .

Mieszko I is regarded as the first historical ruler of Poland. After he died in 992, a civil war broke out between his sons and was won by Bolesław, called the Brave. During his long reign, this Polish duke conducted an expansion in all geographic directions, e.g. he waged several victorious wars with the German Kingdom and the Czechs, who supported the Germans as they struggled to regain Silesia. The wars were waged to keep the then territorial gains as well as to construct an efficient system of collecting fees for the sake of the ruler (the state), thus an effective mobilization system required the implementation of an efficient administrative system, also in Silesia.

The Czech rulers did not abandon the idea of regaining Silesia. They were successful in the 1030s, when the Polish state, after its first king Bolesław the Brave (1025) had died, was overwhelmed by a deep crisis. Poland lost the country of Silesia for some time, and only in the middle of the $11^{\text {th }}$ c. did it regain it when the Polish Duke Casimir the Restorer was supported by the Holy Roman Empire. In the $1^{\text {st }}$ half of the $12^{\text {th }}$ c. Poland was under the rule of a brave duke, Bolesław the Wrymouth. Fighting for independence from Germany, he waged victorious wars with the German King Henry V and the Czechs, who supported him and still struggled to regain Silesia. In his will the Polish ruler divided the country among his several sons, which was a common practice in the then Europe. The document, also called the Succession Statute, came into effect in 1138. Consequently, Poland entered a period of internal fragmentation and long-lasting weakness in political and military terms.
The eldest son of Bolesław the Wrymouth, Władysław, received Silesia and supremacy over his brothers. This lead to a civil war, which ended with Władysław's escape to Germany. After numerous German interventions in defense of his and his offspring's rights, the reign of Silesia was taken over by his son Bolesław the Tall (1173). At the same time, all Silesian lands became effectively subordinated to the Roman (German) Emperor, Frederick Barbarossa.

The descendants of Bolesław the Tall initiated the greatest period in the medieval history of Silesia. Henry the Bearded (married to a Bavarian princess, Hedwig, currently Saint Hedwig of Silesia) and his son Henry the Pious considerably raised the quality of Silesian culture. To illustrate, they developed the settlement with German law on a large scale, which enabled the location of many towns and villages. The privileges given by the rulers to invited settlers contributed to the urbanization of Silesia and made it the richest Polish province and an area which was the most developed in terms of civilization and culture.

The so-called Monarchy of the Silesian Henries tragically came to an end in 1241, when Polish territories were attacked by the Mongols who had come from the conquered Rus'. That year the coalition of Polish dukes and the Czech and German armies was harshly defeated at the Silesian locality of Legnica. Duke Henry the Pious was killed, but after the invaders left Silesia it was restored, also with the help of the new settlers from the West. At that time, there was a lasting rivalry for domination among Polish dukes on Polish territories. It resulted in a period of political weakness. The lands of the Polish state interested the Czech rulers more and more. Gradually, Silesia fell under their influence, being divided into numerous and weak countries. In 1335, the Polish-Czech rivalry for Silesia ended when the King of Poland, Casimir the Great, waived his right to the country to the advantage of King John of Bohemia. Thus Silesian dukes became feudatories under Prague. The province of Silesia became a part of the Bohemian 


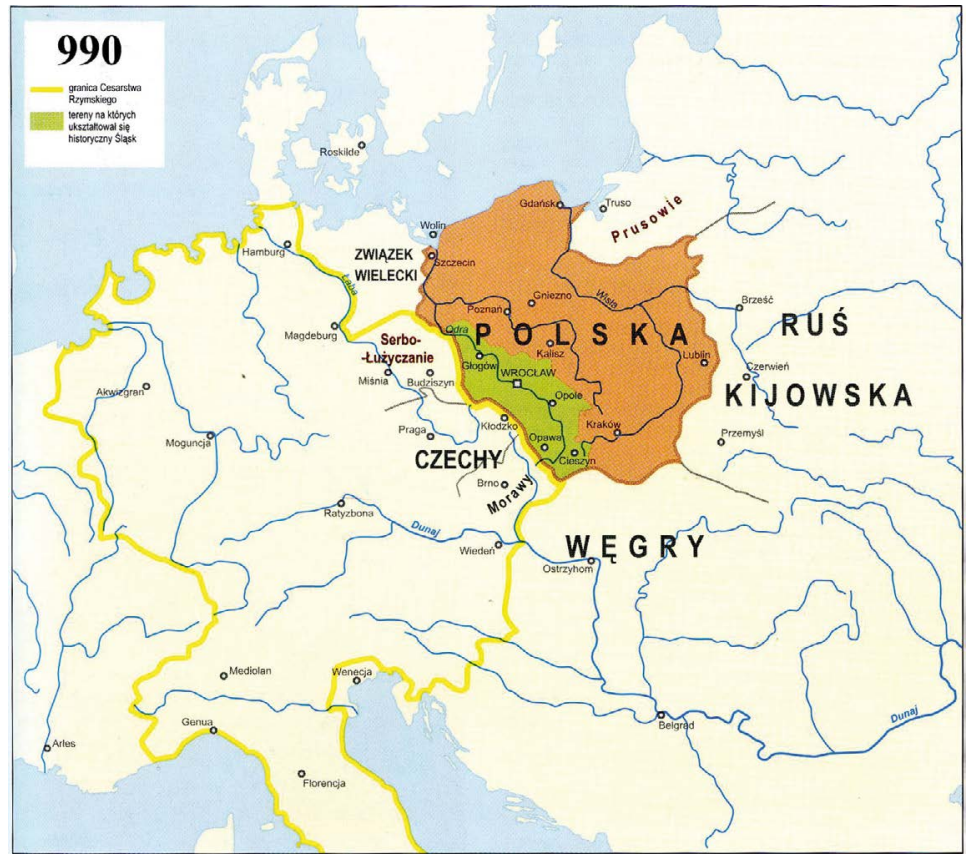

Fig. 1. Silesia was lost by the Czechs to the advantage of Mieszko I, Duke of the Polans. Source: "Wrocławscy kameraliści", vol. 2, ed. A. Bielecki, P. Jastrząb, Wrocław 2005, p. 57

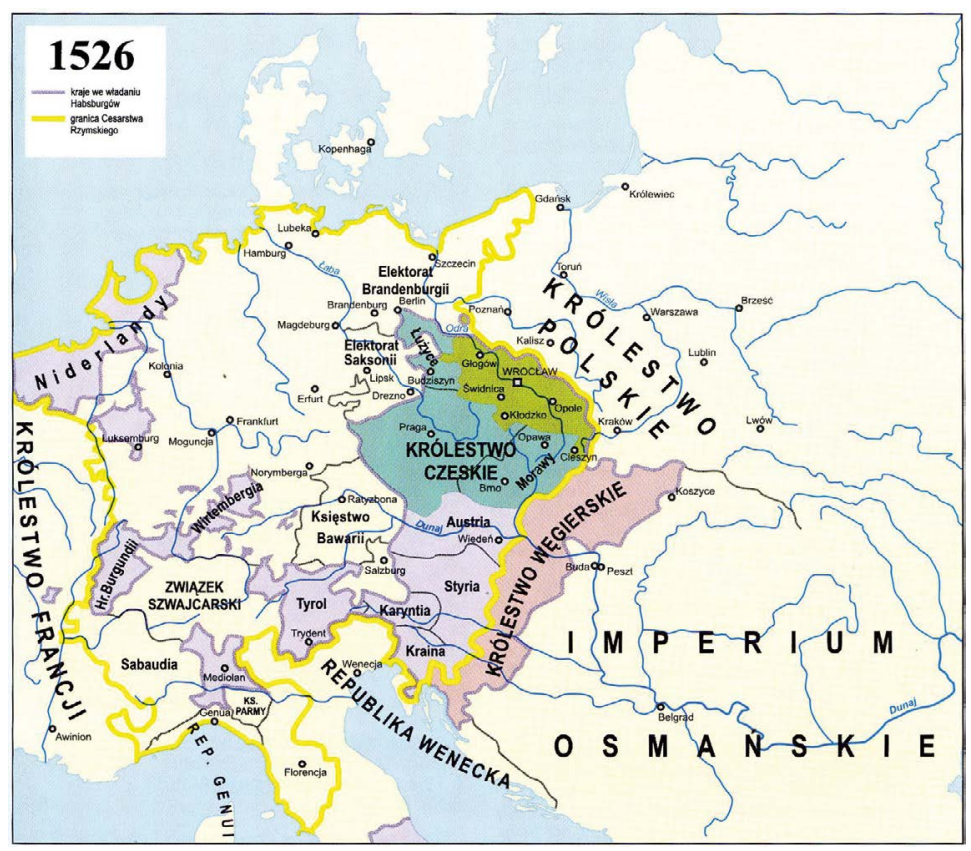

Fig. 2. Silesia and the Kingdom of Bohemia in the Habsburg Monarchy.

Source: "Wrocławscy kameraliści", vol. 2, ed. A. Bielecki, P. Jastrząb, Wrocław 2005, p. 67 


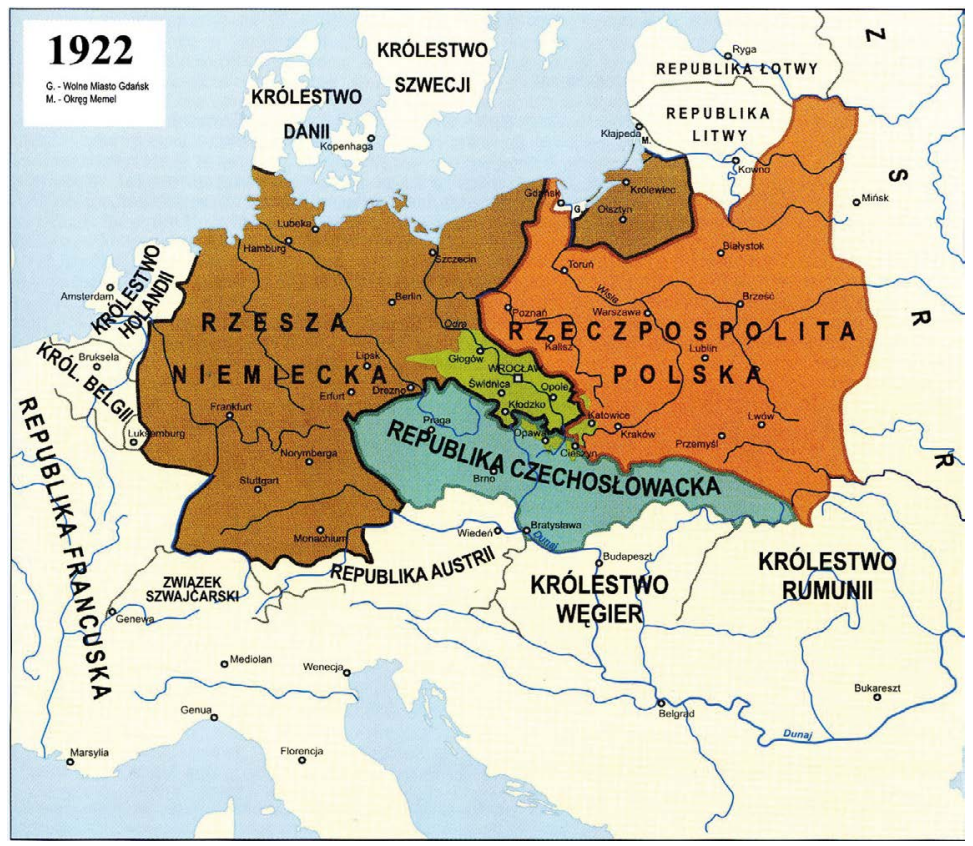

Fig. 3. Silesian territories in Germany, Poland, and Czechoslovakia.

Source: "Wrocławscy kameraliści", vol. 2, ed. A. Bielecki, P. Jastrząb, Wrocław 2005, p. 81

Kingdom, and in 1526 they were both incorporated by the Habsburgs (the area which was under the Habsburgs at that time is presented in figure 2).

This lead to nearly one hundred years of prosperity in the area of Silesia, which saw two significant social processes. First, the German bourgeoisie established its authority in the towns, mainly in the north of Lower Silesia. Second, also in this area Martin Luther's ideas had an enthusiastic reception. Therefore, Lower Silesia became more and more Germanized and Protestant, while Upper Silesia remained an area of Polish ethnicity and Catholicism.

A notable calamity for Silesia was the Thirty Years' War (1618-1648). It resulted in massive damages, depopulation, and an economic decline. Moreover, the Kingdom of Bohemia (including Silesia) became even more dependent on Vienna, and its territories saw a period of ruthless re-Catholicization. In the $1^{\text {st }}$ half of the $18^{\text {th }} \mathrm{c}$., armed rivalry for power began in the German territories between the Catholic Habsburgs and the Protestant,
Prussian Hohenzollerns. The King of Prussia, Frederick the Great, defeated the Habsburgs in the three Silesian Wars and, eventually, in 1763, incorporated Silesia into Prussia. Only some snippets of the province remained under the Habsburgs; the so-called Austrian Silesia. In reverse, Prussia (and Silesia) could incorporate the County of Kladsko, which was historically Czech. Prussian reign brought a ruthless tax policy but also increased the province's significance as an important economic center. This process was supported by reforms that were introduced after Prussia's defeat at the hands of Napoleon. Then a part of Upper Lusatia was joined to Silesia. Throughout the $19^{\text {th }} \mathrm{c}$., Silesia became the center of a prosperous agriculture and, simultaneously, a large center with factories, steelworks, and mining industries. In Lower Silesia, the main industrial center was the province's capital city, Wrocław, and Wałbrzych was the Coal Basin. In Upper Silesia, mainly bituminous coal was extracted and a steelworks industry was developed. In 1871, as a result of the "small" unification of Germany, 
the Kingdom of Prussia, together with Silesia, became a part of the German Reich (Empire).

After World War I (1914-1918), Silesias's situation changed radically. There arose a conflict between the defeated German Reich and the newly formed Slavic states, Czechoslovakia and Poland, which had regained their independence after losing it in 1795. Both states put forward territorial demands towards Silesia, which had so far been under Germany. As a consequence of diplomatic and military conflicts (1919-1922), the country was divided. Czechoslovakia gained a small snippet, the Hlučin Region. After the Polish uprisings (the three Silesian Uprisings) and the Polish-German plebiscite, lost by Poland, Warsaw obtained almost all of the Upper-Silesian industrial area. Berlin, however, preserved Lower Silesia and the agricultural areas of Upper Silesia. The Poland-Czechoslovakia war for Austrian Silesia ended in its division along the Olza River. The above-described division of Silesia among Germany, Poland, and Czechoslovakia is illustrated in figure 3.

Between World War I and II, Silesia remained divided among the three countries. In 1938, Nazi Germany began annexing the Czechoslovakian territories. In that situation, by means of an armed ultimatum towards Prague, Poland annexed a part of the former Austrian Silesia located beyond the Olza River. In 1939, Germany annexed the consecutive areas: the Czech and Moravian territories and some areas of Poland (including its part of Silesia), which was defeated in October. Thus, all Silesian lands were within the borders of the German Reich. In 1945, Adolf Hitler lost World War II, which again changed the territorial situation in Silesia. Prague regained its Silesian lands obtained after World War I; they are currently within the borders of the Czech Republic. Poland gained the German areas up to the line of the lower Oder and the Lusatian Neisse River. Since then, all of Upper and Lower Silesia has been located within Polish borders. On the German side, there are some fragments of the former Duchy of Żagan and the historical Upper Lusatia, which was incorporated into Silesia after the Napoleonic era.

\subsection{Plurilingualism and pluriculturalism in Silesia}

Little is known about the ethnic character of Silesia in the first centuries AD. It is assumed that until about the $5-6^{\text {th }} \mathrm{c}$. they were inhabited by Germanic tribes. Since ca. $7^{\text {th }}$ c., Slavic people probably settled on these territories, for the Germanic tribes, in the Migration Period, burst into the Roman Empire. Slavic traits remained in Silesia under the reign of the Czechs and in the first centuries of Polish supremacy. Then, both countries became Christian and were connected with the papacy in Rome. During the times of Poland's internal fragmentation, and intensely since the beginnings of the $13^{\text {th }} \mathrm{c}$., numerous settlers started coming into Silesian territories from the west of Europe - principally, from the German area. Under the reign of the Silesian dukes, Henry the Bearded and his son Henry the Pious, the German newcomers managed the empty terrains and cleared the forests, created new industrial areas, and established numerous towns and hundreds of new villages, in accordance with German law. Gradually, German traits were acquired by the towns and colonized areas of the Sudeten Foreland. The Polish-Czech rivalry for Silesia ended in the $1^{\text {st }}$ half of the $14^{\text {th }}$ c., when King John of Bohemia won. His domination over the weak Silesian dukes contributed to reinforcing the ethnically German element as well as a rise in Czech cultural influences. Thus Silesia was regarded as a country of three nationalities (Polish, German, Czech), even since the $14-15^{\text {th }}$ c., but its cultural life and civilization achievements were based strongly on ideas flowing from the German area. This tendency was strengthened in 1526, when the Bohemian Kingdom, together with Silesia, came under the Habsburgs. The province started to flourish in terms of culture and civilization. Simultaneously, after 1517, mainly in Lower Silesia, Luther's reformative ideas were very successful. At that time, by the $16^{\text {th }} \mathrm{c}$., the German ethnic character of Lower Silesia was strengthened, whereas Upper Silesia remained mainly Catholic and Slavic in its character. After the Thirty Years' War (1618-1648) and the victory of the Catholic Habsburgs, ruthless re-Catholicization was conducted in Silesia. 
In the $18^{\text {th }}$ c., as a result of the Silesian Wars, almost all of Silesia was joined with Protestant Prussia, which was ruled by the House of Hohenzollern. These rulers did not intend to maintain the Catholic character of Upper Silesia, so in its territories, devastated by the wars, they carried out a colonization campaign by settling the area with a German population. In the $19^{\text {th }}$ c., Silesia underwent significant ethnic changes. During the Spring of Nations (1848-1849), in Upper Silesia there rose up a Slavic group that considered themselves as belonging to the Polish nation. Their views were in opposition to the views of the ethnic Germans, who at the same time started to consider themselves as belonging to the German nation. A very complicated situation rapidly appeared in the highly industrialized Upper Silesia. Most of its inhabitants were of Slavic origin and felt to be primarily "local" people. There were also particular groups that regarded themselves as specifically Polish. Furthermore, at the turn of the $19^{\text {th }}$ and $20^{\text {th }} \mathrm{c}$. there appeared groups considering themselves to be of a separate Silesian nationality. Simultaneously, the area was inhabited by native Germans. Despite the ethnic differences, all of the Upper-Silesian groups were in the German sphere of impact on cultural and civilization. The Polish communities, poorly educated, also lived within a close local culture of a rural character.

When the German Reich lost World War I, Upper Silesia saw a number of ethnic conflicts. The Germans aimed to maintain the territorial status quo. The newly formed Slavic countries, Czechoslovakia and Poland, used the problematic ethnic issues and occupied some territories that had so far been German. In the end, Silesia was divided for well over ten years, mainly between Berlin and Warsaw. Germany kept Lower Silesia, which was inhabited almost exclusively by Germans, and principally the agricultural part of Upper Silesia, with the capital city in Opole. In the latter area, apart from the Germans, there lived thousands of inhabitants of Slavic origin. Some of them felt Polish, some - Silesian, some - German, but the majority presented a regional awareness, i.e. a non-national and non-state one, while the administrative point of reference for them was obviously the German state. On the Polish side of Upper Silesia, the inhabitants represented various nationalities: Germans, Poles, and Silesians, and considerably many people with regional awareness whose number is difficult to estimate. Therefore, in the interwar period both Berlin and Warsaw conducted their ethnic policies that were aimed at either Germanization or Polonization of the Silesian population.

In the first period of World War II, after having defeated Poland, the Nazis reunified all of Silesia, incorporated it into their country and conducted a ruthless policy of Germanization there. They also popularized the concept of National Socialism, especially among children and youth. In 1945, the Red Army started to occupy all of Silesia but allowed for the creation of a Polish administration. Polish communist politicians, subordinated to Moscow, conducted various ethnic and ideological policies in these territories. This was only made easier when in August of 1945 at the Potsdam Conference the victorious world powers sanctioned the incorporation of German territories into Poland, up to the line of the lower Oder and Lusatian Neisse Rivers. The communists, supported by Polish nationalists, strove to deport all of the ethnic Germans, and they almost completely succeeded. Simultaneously, there was a struggle to make the Polish Silesians stay in Poland for economic, political, and ideological reasons. In the part of Silesia which belonged to Germany after World War I, thousands of Silesians were administratively granted Polish citizenship, and thus were accepted as members of the Polish nation. At the same time there were continuous attempts to popularize communist ideas, particularly among children and youth. The Germans deported from Lower Silesia were replaced by Polish settlers. Thus, a complete change in nationality and religion could be observed - Polish Catholics arrived in the place of German Protestants. The mistakes of the policy run in Upper Silesia caused a situation in which for long after World War II thousands of Upper Silesians of Slavic origin regarded themselves 
as Germans - German culture and civilization were simply more attractive for them. Only after 1989, when communism was defeated in Poland and democracy was rebuilt, the German minority was officially recognized. Currently, it counts several hundred thousand people who take advantage of privileges that result from the democratic nature of the Polish state and its EU membership.

\section{Acquisition of knowledge from historical sources}

As regards the rich history of Silesia and despite its consequences, there exists a huge collection of its historical records, although a number of archival materials as well as library and museum collections were lost during the numerous wars. The existing resources comprise, among others, documents referring explicitly and implicitly to the area. They embrace not only old maps but also documents in which are included the names of towns and villages, physiographical objects, and other references of this type. Therefore, in a discussion of such material comprehensive methods which allow to approach the discussed events and phenomena from a broader perspective become particularly important. While designing tools supporting the construction of historical analyses, one must not omit achievements in the humanities and other disciplines. Digitalization and the usage of IT should involve archival collections as well as newer sources, such as atlases and dictionaries.

The profile of Silesia presented above reflects only to a certain extent the multiplicity of motifs that may interest the inquiring researcher.

\footnotetext{
${ }^{2}$ A sequence may be understood in the mathematical sense as a notion that formalizes the intuition to order the elements of a set.

${ }^{3}$ Codex diplomaticus Silesiae, Vol. 1-36, Breslau, 1857-1933.

${ }^{4}$ Schlesische Urkundenbuch, Vol. 1, Bearb. H. Appelt, Vienna-Graz-Cologne 1963; ibidem, Vol. 2, Bearb. W. Irgang, Vienna-Graz-Cologne 1977; ibidem, Vol. 3-4, Vienna-Cologne 1984-1988; ibidem, Vol. 5-6, Cologne-Weimar-Vienna 1993-1998; Breslauer Urkundenbuch, Bearb. W.G. Korn, Breslau 1870.

${ }^{5}$ Regesty śląskie, t. 1: 1343-1348, ed. K. Bobowski et al., Wrocław 1975; ibidem t. 2: 1349-1354, ed. K. Bobowski et al., Wrocław 1983; ibidem, t. 3: 1355-1357, ed. J. Gilewska-Dubis, Wrocław 1990; ibidem, t. 4: 1358-1359, ed. J. Gilewska-Dubis, K. Bobowski, Wrocław-Warszawa 1991; ibidem, t. 5: 1360, ed. J. Gilewska-Dubis, Wrocław-Warszawa 1992.
}

Obviously, during any investigation the primary sources are definitely regarded as basic, while the secondary sources are in second position. In the case of sources of historical data we may speak of their sequences ${ }^{2}$. A primary source may be, e.g. a medieval document (a diploma). This document after processing (e.g. after being deciphered, the shorthand abbreviations explained and then translated) can be placed in diplomatic codices or in the form of summaries, as the so-called regesta. For Silesia, the most significant works of this type are: the Codex Diplomaticus Silesiae, ${ }^{3}$ inc. Regesten zur schlesischen Geschichte, the so-called urkundenbuchs ${ }^{4}$ (meaning 'books of certificates'), Regesty ślaskie ${ }^{5}$ and others. Then the secondary sources become the bases for lexical compilations, an example of which is Stownik etymologiczny nazw geograficznych Ślaska (SENGŚ) - the etymological dictionary of geographic names in Silesia. This multiple transfer of information, according to information theory, poses the risk of various deformations and errors, hence the necessity of introducing verification and correction methods.

Currently, there is access to different kinds of sources, both published (library collections) and unpublished (archival collections), such as: documents, chronicles, geographic descriptions, dictionaries, monographic compilations, etc. A large part of interesting source material is to be found (after their digitalization) in the resources of the Federacja Bibliotek Cyfrowych (Digital Libraries Federation), Europeana.eu and others. Besides the published sources, also archival sources are important but very often still inaccessible, or explored to a small extent or infrequently used in scholarly research.

Very important materials in the investigation of changes that took place within Silesia is e.g. the heritage of Komisja Generalna dla Śląka (German: General Kommission für Schlesien, English: General Commission for Silesia) in Wrockaw, which produced abundant documentation ${ }^{6}$ during its enfranchisement works in 1815-1918,

\footnotetext{
${ }^{6}$ The resources of the National Archives in Wroctaw (fonds number 192) comprise 53396 archival units with $626.5 \mathrm{~m}$ of files (http://archive.is/ DcoCC, access: 15 March 2014).
} 
also in the form of plans and maps. It is only old maps and atlases that constitute an important source of knowledge about the spatial-temporal range of the recorded events and phenomena. The analyses of information they provide allow to obtain descriptive and geometrical data, and in particular, the names, locations, and shapes of objects (the second category of data became more precise when survey cartography appeared). For a set of many sources from different times it is also possible to analyze spatial and temporal dependencies.

The oldest maps of Silesia that are known to researchers are maps from 1544 by Sebastian Münster $^{7}$ and from 1561 by Martin Helwig 8 . Due to the relatively low amount of mapped information they were already elaborated on ${ }^{9}$, or they may be elaborated on with relatively little effort. The subsequent works of cartography, which provide more and more data, require devising methods of automatic or semiautomatic data extraction. In the realization of such tasks, computer systems and the technologies behind them become very useful.

When considering the tools that support effective historical research, one must remember the nature of the analyzed resources and the method in which they are processed. Such tools should ensure access to all elements of the sequence of the sources (if they still exist), preferably online, and should allow to obtain secondary sources if the primary sources are lost. They should also allow to make various analyses, including comparative analyses, and provide the function of browsing together with result filtering.

Using historical resources while employing computer tools is possible only after conducting digitalization. The process usually includes: the

\footnotetext{
7 The oldest map of Silesia, scaled ca. 1:1 071000 , contains about 77 localities and 12 rivers. It was provided in the work of Sebastian Münster, Cosmographia. Beschreibung aller Lender durch Sebastianum Münsterum: in welcher begriffen aller Voelker, Herrschaften, Stetten, und namhafftiger Flecken, herkommen: Sitten, Gebreüch, Ordnung, Glauben, Secten und Hantierung durch die gantze Welt und fürnemlich Teütscher Nation, Basel 1544 - available on the Internet under the following link: http://www.e-rara.ch/doi/10.3931/e-rara-8833 (access: 15 March 2014), on p. 51; http://www.sbc.org.pl/dlibra/doccontent?id=32684 (access: 15 March 2014), p. 42. Index of the digital versions
}

scanning of source materials (documents, paper maps), the processing of obtained images (inc. quality improvement), starting algorithms that extract data (such as OCR - Optical Character Recognition), and orthorectification (done on old maps in order to match them to current frames of geographic references), etc.

As for computer systems and maps, common associations are made with systems of geographic information, such as GIS, or recently, in particular, webGIS (both systems are manageable by means of Internet browsers), but primarily with the SDI (Spatial Data Infrastructure) or ISI (Infrastructure for Spatial Information). This functional range of tools supporting historical analyses stretches far beyond the functions offered by GIS, webGIS, or SDI. If it were possible to compare them with any existing solutions, the systems in which the map element and spatial analyses are only fragments of a larger whole, a platform enabling integration of heterogeneous resources, their finding and visualization should all be considered (not only spatial-temporal). The solution must be something more than an atlas made by means of Adobe Flash (formerly called Macromedia Flash and Shockwave Flash) technology and made available on the Internet - it must be an interactive tool, scalable, and providing services that allow to create added values.

\subsection{Problems with data acquisition from histori- cal sources \\ 3.1.1. Text recognition}

Extraction of data from scanned materials often starts with text recognition. This task, especially for handwritten texts, is not easy, while there is little trouble in recognizing typed writing. Thus the process of text recognition may proceed in available at http://www.univie.ac.at/Geschichte/China-Bibliographie/ blog/2011/01/01/munster-cosmographiae-universalis-libri-vi/ (access: 15 March 2014). The Latin title of the edition from 1554 reads Cosmographiae universalis Libri VI.

${ }^{8}$ The map scaled ca. 1:530 000 contains 306 localities (towns, villages, castles, monasteries) and over 50 rivers.

${ }^{9}$ The selected compilations: J. Janczak, Zarys dziejów kartografii śląskiej do końca XVIII wieku, Opole 1976; B. Czechowicz, Historia kartografii Śląska XIII-XIX wieku, Wrocław 2004; idem, Visus Silesiae. Treści i funkcje ideowe kartografii Śląska XVI-XVIII wieku, Wrocław 2008. 
different ways, depending on the character of the source being processed. Usually this is started by spotting the localization of the text, when such obstacles must be faced as various directions and colors of the inscriptions on the material, various fonts (in the case of typed writing), or various versions of the language that was used. When the map scans are processed, additional difficulties may take place that are not encountered when working with textual documents, such as a text with accompanying objects (road systems, hydrographical elements, topographical symbols, etc.), information overload (the overlapping of inscriptions, signatures, and other elements), and a non-uniform background. All of this considerably hinders an automatic interpretation of the map's contents.

\subsubsection{Reconstruction of the historical scenery on the basis of an automatic analysis of old maps}

In order to conduct a proper reconstruction of the historical scenery on the basis of old maps, an appropriate methodology must be developed. It seems that the retrogression method is the right approach. However, in order to apply it a method of processing the analyzed sources should also be developed.

Paper maps are not applicable to any computer service. They can only be referenced to, like books or other sources. Two actions must be performed in order to make paper maps available to computers and the web. First, the maps have to be scanned with possibly small distortions. Scanners are currently in common use, but the scanning of maps is more problematic than, e.g. a tiny sheet of paper. Maps are large, folded, may be bound in atlases - all of this makes scanning maps difficult. Once the map has been scanned, in other words there is a digitized map, it is still only a picture. In order to convert it into an actual digital map that is presentable and usable in GIS systems, the process of georectification (sometimes also called calibration) must be done. Only such maps enable an accurate depiction of, e.g. the course of historical boundaries. In fact, this process consists of finding the function which may be associated with any of the pixels of its geospatial coordinates in the chosen coordinate system. The WGS-84 is widely used in the world of the GIS coordinate system. In this system, coordinates consist of three numbers - latitude, longitude and ellipsoidal altitude. Maps drawn in the WGS-84 do not allow to obtain the Euclidean distance in a simple way. Local coordinate systems, such as UTM or PUWG-2000 (according to regulations of the Polish government $)^{10}$, allow it but are limited to a broader area of applicability.

From the georectifier's point of view, maps can be divided into certain categories. First, maps may already be adopted to the WGS-84 system - this is the simplest category, as georectification is reduced to pointing some coordinates on the border or grid of the map in calibrating programs, such as OziExplorer (http://www.oziexplorer.com) or QuantumGIS (http://www.qgis. org/pl/site/). Only some contemporary maps belong to this category. Also, maps from existing services that publish maps with calibrating data (e.g. The Archive of Maps of West Poland) ${ }^{11}$ fall into this category.

The second category contains maps printed in another known (described in the legend) coordinate system and projection. For these maps one has to choose the correct projection and again show some points on the border. The majority of maps printed in the $20^{\text {th }} \mathrm{c}$. belong to this category.

The third category includes maps drawn in an unspecified projection and coordinate system but with geographical coordinates on the border. Some maps printed in the $19^{\text {th }}$ and $20^{\text {th }} \mathrm{c}$. fall into this category. They need some historical and cartographic investigations to find the most probably used projection and datum. An example of this kind of map is Hellmich's map shown in figures 4 and 11 .

Knowing the year and country (the beginning of the $20^{\text {th }}$ c., Germany) of when the map was published and its scale, we can assume hat the projection that was used was the

\footnotetext{
${ }^{10}$ Rozporządzenie Rady Ministrów z dnia 8 sierpnia 2000 r. w sprawie państwowego systemu odniesień przestrzennych, "Dziennik Ustaw Rzeczypospolitej Polskiej", 70, 2000, item 821.

${ }^{11}$ Archiwum Map Zachodniej Polski (http://mapy.amzp.pl/).
} 
Lambert Conformal Conic and the datum is Potsdam-Rauenberg.

After putting the data into the calibrating program (fig. 5) and obtaining the calibration

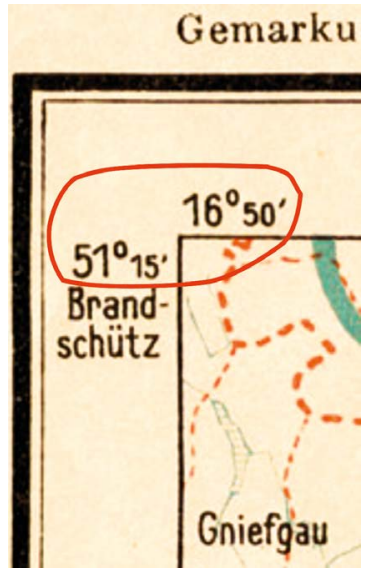

Fig. 4. Geographical coordinates on the border of the map file, we can check the quality of the process by overlaying the map with a contemporary one. The result of overlaying Hellmich's map with a contemporary vector map ${ }^{12}$ is shown in figure 6 - it is better than we expected. In order not to make the underlying map too complex, only the main roads and rivers are shown.

Unfortunately, there are also worse cases. Wieland-Schubarth's map (1752), which belongs to the fourth category, has geodetic coordinates shown on the border and information that the reference meridian is $20^{\circ}$ from Paris. This meridian was commonly used in Europe under the name Ferro (el Hierro), before the Greenwich meridian was accepted. The projection remains unknown. The result shown in figure 7 (also overlaid by the contemporary map $)^{13}$ is worse than in the previous case, the offset is ab. $8 \mathrm{~km}$ and is diverse throughout the map. The conclusion is that more investigation regarding this map is needed.

Older maps are even more difficult to calibrate because no coordinates were put on the maps, and the datum and projection are unknown.

For maps of the fifth category, we can try to use known points (e.g. churches, towers,

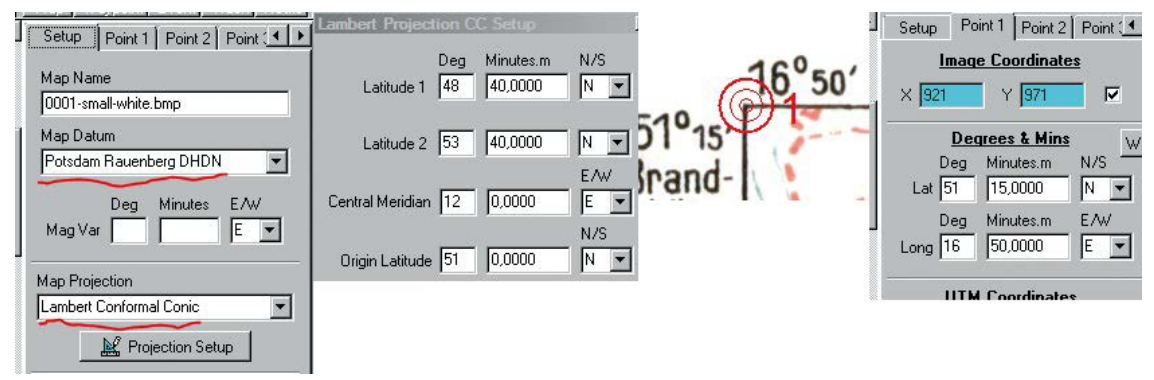

Fig. 5. Example of calibrating a map

\footnotetext{
${ }^{12}$ From the sources of the UMP published also as a web service at http:// mapa.ump.waw.pl/ump-www/ (access: 15 March 2014). 
castles) that are drawn on it in the calibration. The main problem to be solved in this case is the selection of correct objects as the calibrating points. They should have a known location; moreover, the location must be invariant in time. The boundaries of administrative divisions or riverbanks are wrong options because their position is subject to change. Therefore, choosing the calibration points and their coordinates requires special procedures. It may, for example, involve an analysis of preserved monuments of cartography, particularly those containing social content, comparing the modern topography with the settlement pattern. Since an inventory (gathering) of available collections of historical maps of Silesia, with particular emphasis on thematic maps (administrative, settlement, economic, etc.) is planned, these problems will have to be dealt with.

The sixth category of maps contains mostly ancient maps but also plans and sketches drawn or engraved without a scale. These maps should

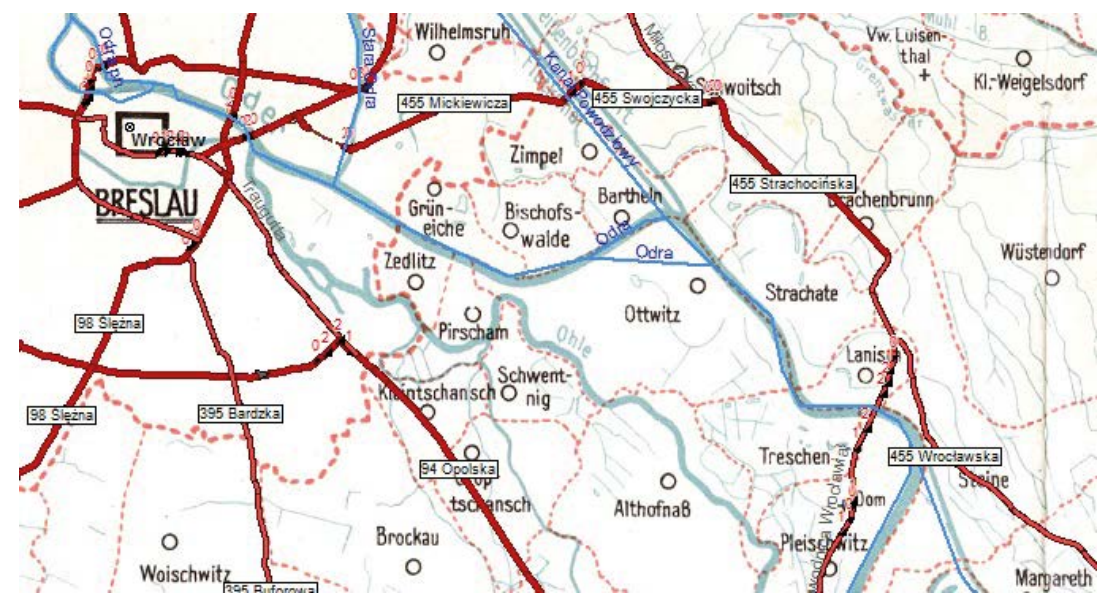

Fig. 6. Result of calibrating Hellmich's map

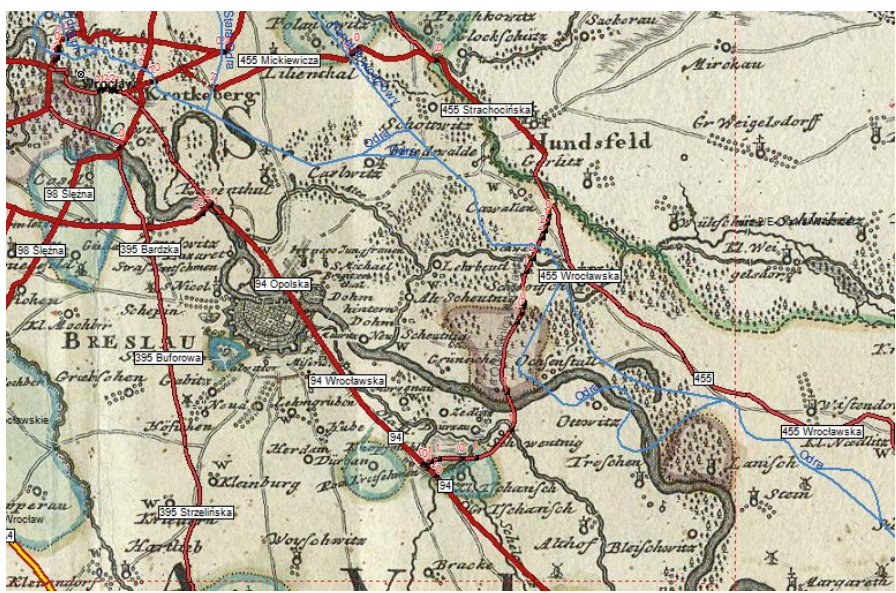

Fig. 7. Result of calibrating the Wieland-Schubarth map 
be treated as imaginations of artist rather than as resources describing exact spatial relationships of specific features. Moreover, sometimes they incorporate topological errors. From this reason georectification of such maps (even using so called "rubber sheeting") is very difficult and does not make sense.

\subsection{Available sources and their potential use}

For the Silesian territories, especially of the last three centuries, there exists quite a rich collection of sources, dictionaries, and atlases. These materials may constitute the basis for the creation of an electronic historical gazetteer of Silesia, a geospatial service (as it creates an infrastructure of the spatial information) that will make available the categorized information and enable geocoding, which is eliciting the geographical coordinates of an object on the basis of its name or other data.

\subsubsection{Dictionaries}

The most precious lexical source from the end of the $18^{\text {th }} \mathrm{c}$. is a multi-volume geographical-statistical description of Silesia written by Frederick Albert Zimmermann $^{14}$. Of a similar character is also the compilation by Johann Georg Knie: Alphabetischstatistisch-topographische Uebersicht der Dörfer, Flecken, Städte und andern Orte der Königl. Preuß. Provinz Schlesiens (1845). An impressive work referring to Polish territories became the Stownik geograficzny Królestwa Polskiego i innych krajów stowianskich (The Geographical Dictionary of the Polish Kingdom and Other Slavic Countries), which was a joint publication in volumes (Warsaw 1880-1902). A variety of historical dictionaries are toponym lexicons of a linguistic profile. These cover and elaborate on local names, names of physiographical objects, etc. A fundamental and very useful lexicographic work is the already mentioned SENGŚ. Up until now, 17 volumes have been published. A name entry embraces the following names:

1. modern official names together with their variants, the character of the object and its localization;

${ }^{14}$ F.A. Zimmermann, Beyträge zur Beschreibung von Schlesien, Vol. 1-13, Brieg 1783-1796.
2. historical material arranged chronologically, together with a transliteration of the form and year of the record, the status of the source, volume and page numbers, and the number of the document if possible;

3. the etymological description.

An exemplary entry is presented in figure 8 .

An analogous source that refers to the territory of the whole country is the Nazwy Miejscowe Polski (Lexicon of Polish Local Names). The work was initiated by Kazimierz Rymut, and so far it has been published only partially, up to vol. $12(R u-R \dot{z})$. Furthermore, it is a source that provides fewer names than SENGŚ, since localities that did not previously constitute independent units were not included.

With regard to the Czech part of the area which we are interested in, we may refer to the works of Czech researchers, such as Ladislav Hosák and Rudolf Šrámek. Their dictionary, Mistni jména na Moravě a ve Slezsku, comprises 5570 entries covering, among others, the toponymy of the Czech part of Silesia. It discusses the following historical and linguistic elements:

1. the profile of the village according to the state in 1935 - its localization, additionally marked Sl. if in Cieszyn Silesia or Opavian Silesian, or enkl. if in Moravian enclaves;

2. the historical variants of the local names;

3. localization in the dominal areas in $\mathbf{1 8 4 8}$ and the most crucial data from local history;

4. folk dialectal variants of the local names;

5. etymological explanation of the names;

6. the names of selected historical parts of the localities and of the houses located on the byways.

The compilation also embraces a register of the names' alternations between May 5, 1945 and January 1, 1972, and the index of names that vanished then which enables to sport the changes that occurred during that period.

According to the conclusions of the Congress of Vienna (1814-1815), Prussia obtained the Lusatian areas from Saxony. The political change entailed administrative changes, and Upper Lusatia was joined to the Prussian province of Silesia $(1815,1825)$. For Saxony, there exist publications such as Historisches Ortsverzeichnis 
von Sachsen and Historisches Ortsnamenbuch von Sachsen. An electronic version of the first of these dictionaries is available on the Internet by means of a project called Digitales Historisches Ortsverzeichnis von Sachsen (www.hov.isgv.de), created by the Institut für Sächsische Geschichte und Volkskunde. The dictionary covers the following elements:

1. geographic location;

2. the state (German: Verfassung) considering: a) the type of settlement and municipality affiliation, b) the state of the previous conditions, c) landowner, d) emptied areas;

3. forms of settlement (Siedlungsform und Gemarkung);

4. population (Bevölkerung);

5. affiliation to the judicial authority (Verwaltungszugehörigkeit);

6. land property (Grundherrschaft);

7. ecclesiastical arrangement (Kirchliche Organisation);

8. varieties of local names (Ortsnamenformen);

9. sources;

10. Gauss-Krüger coordinates (only in the printed version).

\subsubsection{Maps}

Due to the adopted method of regression, the analysis of a map should be commenced via a reference to contemporary maps. Only then should maps from previous periods be investigated. For years in Poland, classic topographical maps were paper-published by the Centralny Ośrodek Dokumentacji Geodezyjnej i Kartograficznej (CODGiK - National Center for Geodetic and Cartographic Documentation) and other publishers. Some of them are de facto historical maps that are no longer valid nowadays (they were still up-to-date in the $2^{\text {nd }}$ half of the $20^{\text {th }}$ c.). Previous Polish cartographic sources are maps and geographical materials published by the Wojskowy Instytut Geograficzny (WIG The Military Institute of Geography) from 1919 until 1939.

For an investigation of the history of Silesia, besides the contribution of Polish cartography, also compilations from other countries are very important, e.g. from Prussia, Austria, Germany (inc. the GDR), and the Czech and Czechoslovakian states. Apart from the most contemporary sources, it is also worth studying
ŁANY, -ów (Lanisch), wś, gm. Czernica, wroc.: Lanschener 1412 H 102; Lanisch 1464 Dom 81; Lanisch 1743 WAPWr 1, 70; Lanisch 1795 Z XII 192; 1845 K 351; Myc 70; R s.v.; PRL 619; Wyk II 332; 2. (Lohnau), wś, gm. Cisek, opol.: von Lan 1295 CS VII/3, 228, Lan 1428 CS VI 52, czu Lany 1488 CS VII/1, 143; Lany 1567 Urb 226; in pago Łonn 1679 J II 159, Laning 1680 J II 643, Lana 1687/88 J II 493; Lahny 1743 WAPWr 1, 9; Loni, też Lohnau, Lony 1783 Z II 306; Lohnau 1845 K 378; 1864 Triest 911; 1886 OET 20; L 78; D 150; Myc 36, 71; Eony, Lohnau 1939 Prus 48; Lanisch 1941 SOV 210; Fl 619; gw. uuny N 249; R s.v.; PRL 619; Wyk II 332; 3. (Hubenland, Lohnia), wś, gm. Rudziniec, kat.: Lana Virbece, Lana Colende, Lana Stesconis ok. 1300 CS XIV 95; in pago Lania 1679 J II 151; Lahny 1743 WAPWr 1, 6; Lahny 1745 PAPGl 15; Lohnia 1783 Z II 343; (1416 Lanow // Lonia) 1845 K 379; Lohnia ^. 1886 OET 56; $1896 \mathrm{D}$
N. kult. Łany 1. mn. od wyr. tan, zob. Lan Kopert 114; Rymut, Krak 94. Ad 1 Zapisy historyczne wskazuja na pierw. ${ }^{*}$ Eaniszcze, tj. n. kult. oznaczająca 'miejsce, gdzie był łan' Dom 81. Ad 3 Niem. Hubenland - chrzest germanizacyjny z 1936 r. Ad4 N. przeniesiona z n. m. Łany (cz. Woźnik). Oboczna forma Lana $\leftarrow$ niem. Lany-Fluss.

Fig. 8. Example of a SENGŚ entry that refers to the village of Łany.

Source: SENGŚ, vol. 7, ed. S. Sochacka, Opole 1994, p. 47 
old maps, e.g. the map by Helwig which initiated the development of Silesian cartography. Its instances from the $17^{\text {th }} \mathrm{c}$. are works by Jonas Skultetus (1603-1664) and Frederick Kühn (d. 1675). The first official cartographic picture of Silesia was taken thanks to activity started in 1722 by Johann Wolfgang Wieland and continued by Mattheus von Schubarth (a fragment of a map with the surroundings of Wrocław is presented in figure 9). These constructed maps of Silesia were published in the form of an atlas only in 1752 - thus after the incorporation of Silesia into Prussia and after an administrative change that consisted in the creation of two chambers with the capital cities in Wrocław and Głogów. However, the published maps complied with previous conditions and presented the division into duchies. Thanks to this they constitute valuable historical documentation of the political relations traced back to the Late Middle Ages.

The following maps of survey cartography were created as a result of surveys carried out by Christian Friedrich von Wrede, Ludwig Wilhelm Regler, Daniel Gottlob Reymann, and others. Upon the order of the Prussian King Freder- ick the Great, in the years 1747-1753 Wrede conducted new cartographic surveys of Silesia, as previously constructed maps did not fulfill the military aims because they were too general (scales from ca. 1:100 000 to ca. 1:200 000). Thus the atlas Krieges Carte von Schlesien comprising 195 handwritten sheets scaled 1:33 333 was created (a fragment of the map with the surroundings of Wrocław is presented in figure 10). A notable and complex compilation of maps from 1764-1770 was a work by Ludwig Wilhelm Regler titled Schlesien links der Oder ohne die Grafschaft Glatz.

Important data sources for Silesia of the $19^{\text {th }} \mathrm{c}$. and the $1^{\text {st }}$ half of the $20^{\text {th }} \mathrm{c}$. are Prussian topographic maps, the so-called Messtischblatts, scaled 1:25 000, and older Urmesstischblätters. Unpublished handwritten sheets of the Urmesstischblätters are to be found in the Berlin State Library (Staatsbibliothek zu Berlin). Another important collection is the Weimar atlas of Silesia: Topographisch-militarischer Atlas von dem souverainen Herzogthume Schlesien mit Oesterreichisch Schlesien und dem dermahlen zum Herzogthum Warschau gehörigen Neu Schlesien in 26 Blättern

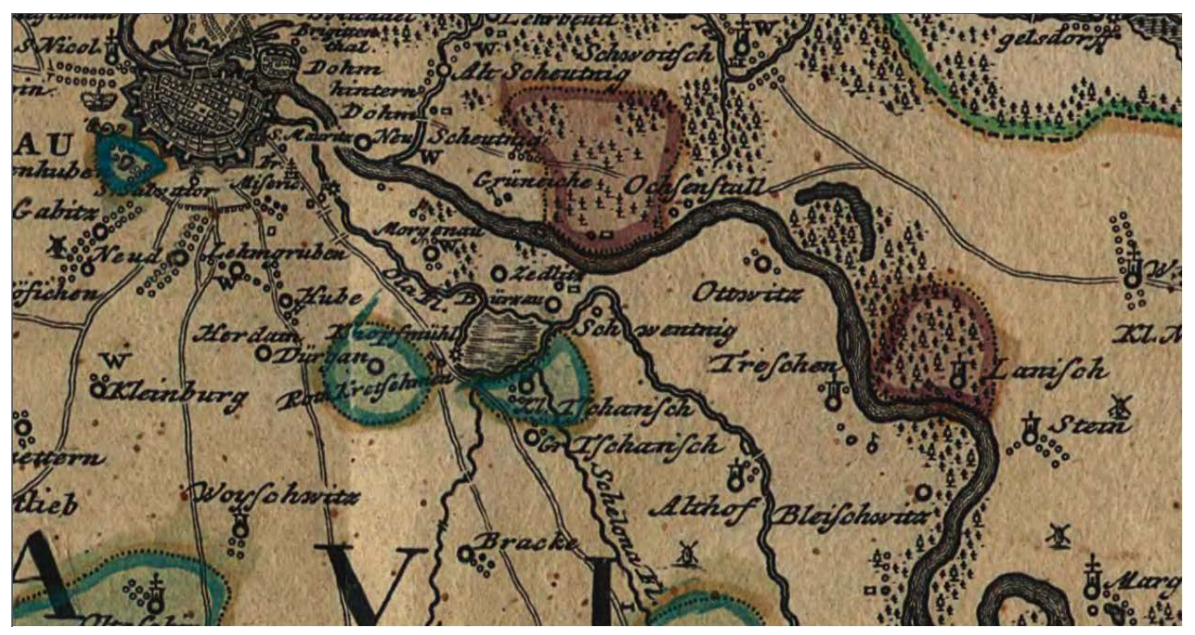

Fig. 9. Wroctaw and the surrounding areas on Wieland and Schubarth's map.

Source: J.W. Wieland, M. von Schubarth, "Principatus Silesiae Wratislaviensis", scale: 1:125 000 (http://www. bibliotekacyfrowa.pl/dlibra/doccontent?id=34247, access: 20 October 2016) 
(1809). For a reconstruction of the historic political and administrative borders, also other compilations are useful, including four sheets of the Grundkarte von Schlesien by Max Hellmich which present the borderlines of land units within the municipalities (German: Gemarkungen). Figure 11 presents a fragment of Hellmich's map that shows the surroundings of Wroctaw.

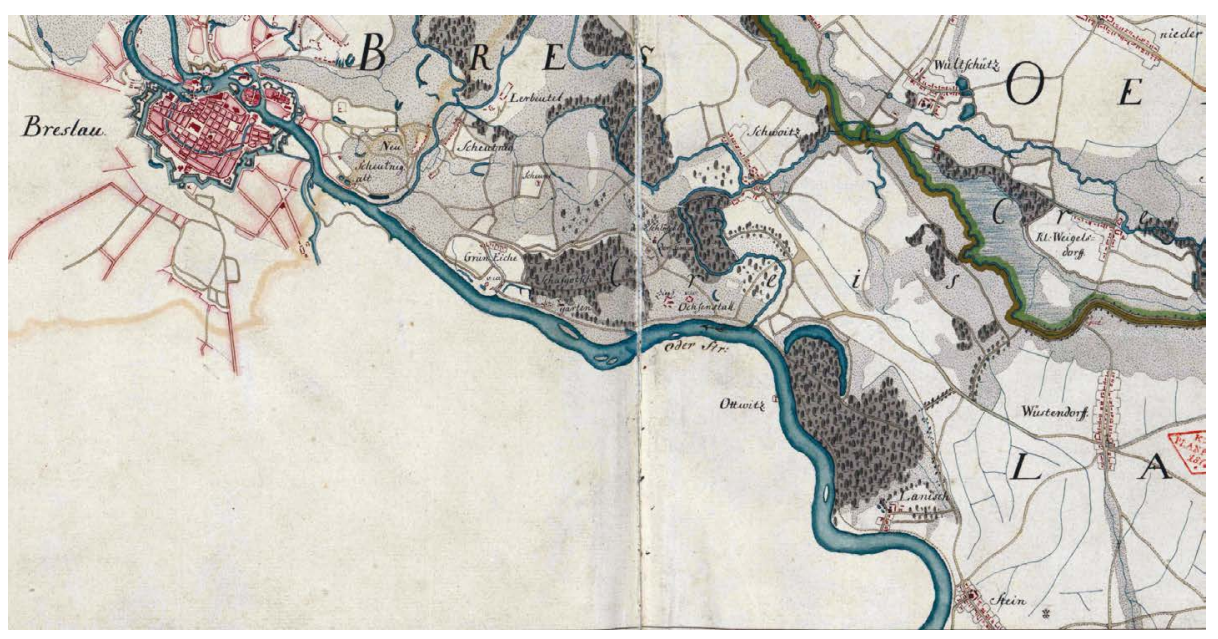

Fig. 10. Wroctaw and the surrounding areas on Wrede's map.

Source: Ch.F. von Wrede, "Krieges-Carte von Schlesien", scale: 1:33 333, Vol. 5, S. 32

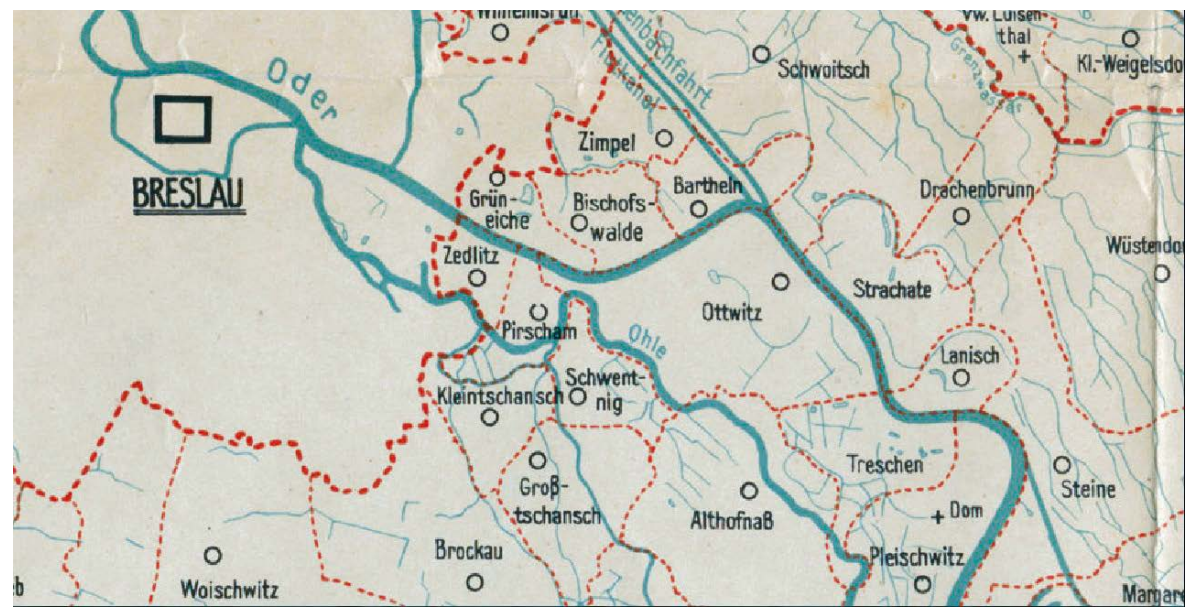

Fig. 11. Surroundings of Wroctaw on Hellmich's map.

Source: M. Hellmich, "Grundkarte von Schlesien. Blatt Breslau", scale: 1:100 000 (http://www.bibliotekacyfrowa. pl/dlibra/doccontent?id=41894, access: 20 October 2016) 
4. Technical aspects related to the management of historical sources and the presentation of historical analyses

When designing computer systems that support conducting historical analyses, the following elements should be taken into consideration: geospatial services (inc. gazetteers) and map components that are constructed based on them, metadata systems, and semantic knowledge bases, such as dictionaries and thesauri.

A map component should provide referential data which gives the opportunity to display various types of information graphically, also historical information. A clear relation between a map and statistical data as well as presenting selected data in intelligible tables and charts not only facilitates work on the analyzed resources but also contributes to their better perception. From the technological point of view, such a degree of flexibility may be achieved when the appropriate map website is started. Then, thanks to the creation of intelligent clients of such a website, the map can have not only an illustrative function but also become an interactive platform that will integrate information from multiple sources. All the more since there already exist map websites in Poland which may be used in comparative analyses in examining the courses of historical processes.

In general, a gazetteer is a dictionary of names and terms that have spatial referents and provide information about their localization, frequently expanded with values of descriptive attributes. From gazetteers it is possible to obtain information about the spatial relations that are to be found among the processed sources. Currently, there are several registers in Poland that are used as gazetteers.

One of the gazetteers is Krajowy Rejestr Urzędowy Podziału Terytorialnego Kraju (TERYT - The State Official Register of the Territorial Division of the Country) and Państwowy Rejestr Nazw Geograficznych (PRNG - The State Register of Geographical Names). There also exist institutions that control referential data and the nomenclature that is used, such as the Komisja Standaryzacji Nazw Geograficznych (Commission on Standardization of Geographical Names) together with the Komisja Nazw Miejscowości i Obiektów Fizjograficznych (Commission on the Names of Localities and Physiographical Objects), which is an advisory body.

The TERYT register obtains data in the following systems: TERC (identification codes and names of territorial division), SIMC (identification codes and names of localities), BREC (census and statistical districts), NOBC (address identification of roads, immovable properties, buildings, and flats), ULIC (central catalogue of roads). The identification codes provided by the TERYT register are useful to authorities that keep official records and run information systems of public administration. They also allow for an analysis and presentation of socio-economic phenomena to different extents of particularity, e.g. provinces (województwa), counties (powiaty), municipalities (gminy), districts (dzielnice and delegatury) in urban municipalities, statistical regions (rejony obwodowe) and census constituencies (obwody spisowe), localities and roads, but also in the division into towns and villages.

PRNG is a referential database of public administration that functions at the central level and is maintained by the CODGiK. It includes information and data on the localization of geographical objects in the area of the Republic of Poland: settlement objects (localities), physiographical objects, and natural objects. It is updated continuously on the basis of legal acts on the setting, changing or abolishing of names (for official names), and as a consequence of verification and supplementation with information included in other collections and registers that refer to geographical names (for the remaining names).

Worldwide there are more commonly known gazetteers and websites, such as Geonames ${ }^{15}$, $\mathrm{GNS}^{16}, \mathrm{ADL}^{17}$, JRC Fuzzy Gazetteer ${ }^{18}$, or The Getty Thesaurus of Geographic Names ${ }^{19}$.

\footnotetext{
${ }^{15}$ GeoNames (http://www.geonames.org/, access: 24 July 2016).

${ }^{16}$ Geographic Names Database (http://geonames.nga.mil/gns/html/, access: 24 July 2016).

${ }^{17}$ Alexandria Digital Library Gazetteer Server (http://www.alexandria.ucsb. edu/, access: 24 July 2016).

${ }^{18}$ Joint Research Centre Fuzzy Gazetteer (http://dma.jrc.it/services/fuzzyg/, access: 24 July 2016).

${ }^{19}$ Getty Thesaurus of Geographic Names (Getty Research Institute) (http:// www.getty.edu/research/tools/vocabularies/tgn/, access: 24 July 2016).
} 
Metadata systems are used to create descriptions that serve as indices on the basis of which the resources may be catalogued and then searched for.

Knowledge bases provide a certain notion model that is described formally and available to be processed via computer with the usage of the so-called inference engine. Thesauri may be regarded as knowledge bases, for they embrace hierarchically and semantically interrelated terms and definitions that are elaborated on for one or many languages and controlled dictionaries (a list of words and phrases that are accepted to be indexed). Knowledge bases, filled with facts, may be like a mother lode of notions and relations between them which could be employed in different conditions on condition that they become open on demand from the level of both client applications and program automats. Therefore, they should be implemented as services with a properly defined interface and a standardized data model. One can realize the potential of domain knowledge bases by analyzing the range of applications of such thesauri as GeoNames, GEMET ${ }^{20}$, AGROVOC ${ }^{21}$, EUROVOC, A\&AT ${ }^{22}$, Getty Thesaurus of Geographic Names, and the UNESCO Thesaurus ${ }^{23}$.

A spatial analysis algorithm, available in GIS systems, domain knowledge bases, gazetteers, and metadata systems may be used to create tools for searching for information. They constitute the basis for the construction of intelligent tools that support users in conducting analyses.

\subsection{Usage of geospatial web services}

Advances in the development of information technology have manifested themselves by: increased bandwidth of communication channels, development of new web publishing methods and tools, and implementation of web browsers

\footnotetext{
${ }^{19}$ Getty Thesaurus of Geographic Names (Getty Research Institute) (http:// www.getty.edu/research/tools/vocabularies/tgn/, access: 24 July 2016).

${ }^{20} \mathrm{GEneral}$ Multilingual Environmental Thesaurus (https://www.eionet.europa.eu/gemet/, access: 24 July 2016).

${ }^{21}$ AGROVOC Multilingual agricultural thesaurus (http://aims.fao.org/standards/agrovoc, access: 24 July 2016).

${ }^{22}$ Art \& Architecture Thesaurus (Getty Research Institute) (http://www.getty. edu/research/tools/vocabularies/aat/, access: 24 July 2016).
}

and search engines. These enable the implementation of advanced methods of geospatial data sharing and visualization.

Substantial actions that have increased the statistics of geospatial data usage were the publication of map services and location-based services within the scope of Google Maps (https:// www.google.pl/maps, access: 24 July 2016), Yahoo Maps (https://maps.yahoo.com, access: 24 July 2016), MapQuest (https://www.mapquest. com, access: 24 July 2016), Bing Maps (http:// www.bing.com/maps, access: 24 July 2016) services, launching community-driven initiatives such as OpenStreetMap (https://www.openstreetmap.org, access: 24 July 2016), UMP-pcPL (http://ump.waw.pl, access: 24 July 2016), and the implementation of an infrastructure for spatial information maintained by public administration.

The information systems have to be interoperable in order to interact. This interoperability can be achieved through standardization. The main subjects of standardization efforts are those related to the architecture of the information systems, services and their interfaces, protocols along with the definition of structures of the data being exchanged. In geographic information science there are two main standardizing organizations that are responsible for designing geospatial standards: ISO/TC211 (International Organization for Standardization, Technical Committee 211, Geographic Information/Geomatics) and OGC (Open Geospatial Consortium). The standards developed by these organizations are used in various specifications, such as in implementation rules and technical specifications defined for public administration implementing infrastructure for spatial information in accordance with the assumptions of the INSPIRE Directive.

Geospatial services can provide reference data in raw (original data) or processed (published map) forms. Thanks to this the creation of added values and the construction of additional services combining the functions of map

\footnotetext{
${ }^{23}$ UNESCO Thesaurus (http://vocabularies.unesco.org/browser/thesaurus/ en/, access: 24 July 2016).
} 
presentation with the capabilities of searching and processing of related information is possible. Thus the main aim of building geospatial services does not focus exclusively on offering static, once-generated studies, it is rather oriented at providing information that meets the needs of individual consumers and can be used in a wider context.

A clash is observed between the old-fashioned (printed maps and atlases) and new technologies (e.g. GIS) of geospatial data presentation. Both traditional and electronic media of the publication of maps and atlases are specific, so it is actually not easy to determine any advantage of any type. To illustrate, on the computer there is no limit as to the size of a piece of paper - virtual reality spreads far beyond the area that a web browser is designed to relate to. However, the number of details that may be presented at a time on the computer screen is not to be compared with large-format printouts. On the other hand, an electronic data medium enables the usage of presentation methods that are unavailable on paper, such as animations, three-dimensional models, additional multimedia. This, in turn, allows to present historical phenomena, events and processes in an innovative and dynamic way, enriched in the virtual reality.

An example of a portal with information on historical sites is accessible under the following URL: http://www.dobroni.pl/miejsca.html (access: 15 March 2014). This portal offers maps (taken from Google Maps) enriched with addi- tional informative elements plus forms and controls for an information search.

The products offered with the aid of map services can be generated in a dynamic way. This can be illustrated in an example of portrayal services that provide maps with the content generated according to the parameters defined by the user (the methodologies and techniques used for a dynamic, interactive map design preserving cartographic principles and their automation are the subject of a new research field called neocartography).

The possibility of defining symbols or styles to represent selected objects on the fly is particularly suitable for the generation of maps parameterized by time, e.g. when the map content includes some battlefields and the time period considered is before the invention of firearms, then a symbol with crossed sabers can be used to represent these places. When the time shifts after the withdrawal of white arms, a symbol of crossed rifles can be used instead (examples of such symbols are presented in figure 12, more publicly available symbols can be found at http://wiki.osgeo. org/wiki/OSGeo_map_symbol_set, access: 15 March 2014).

The implementation of such a portraying method is relatively simple (for the results see figure 13). The request sent to the service includes a parameter that specifies the style of presentation. A definition of this style should be compliant with the SLD standard ${ }^{24}$. This standard has to reach a syntax for defining the
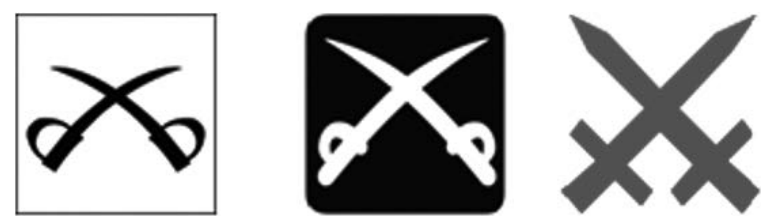

Fig. 12. Examples of symbols used to denote battlefields on historical maps.

Source: http://www.ordnancesurvey.co.uk/resources/maps-and-geographic-resources/map-symbols. html, access: 15 March 2014; http://trac.osgeo.org/qgis/browser/trunk/qgis/images/svg/tourist/ tourist_battlefield.svg, access: 15 March 2014; http://wiki.openstreetmap.org/wiki/File:Battlefield. svg, access: 15 March 2014

\footnotetext{
${ }^{24}$ SLD is an abbreviation for Styled Layer Description - an XML-based markup language designed by Open Geospatial Consortium and used for expressing styling of geospatial data in a standardized way.
} 
way objects should be rendered on the map. It allows, in particular, to define the rules on the style with respect to object attributes. An example of a map request from the WMS (Web Map Service) can be written as follows:

http://localhost:8080/.../ wms ? service $=$ WMS \& vers ion $=1.1$ .0 \& request $=$ GetMap $\&$ layers $=\mathrm{s} I$ ask: bitwy\&bbox $=17.03195678$ $38365,50.9302777705744,17.3$ $02500000493,51.116666658959$ $4 \&$ width $=512 \&$ height $=352 \& \mathrm{sr}-$ $\mathrm{s}=\mathrm{EPSG}: 4326 \&$ format=image $/ \mathrm{png}$

Information about the desired map style can be incorporated in such a request by referencing to the style file available on the Internet (this can be done by providing additional parameters SLD=http://host/style.sld) or by URL encoding of this style definition directly in the request (adding a parameter SLD $\mathrm{B} O \mathrm{DY}==\div 3 \mathrm{C} \div 3 \mathrm{~F} \times \mathrm{ml}+\mathrm{Ver}-$ sion $\div 3 \mathrm{D} \div 221.0 \div 22+\ldots$. . If the server offers predefined styles on its side, these styles can be referenced by name in the STYLES parameter. A part of the SLD style file is presented below. In this example the external icon is declared which should represent an object with point geometry.

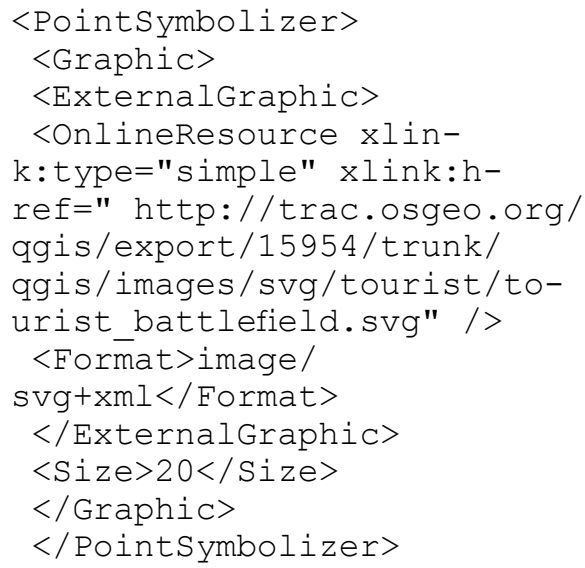

$<$ PointSymbolizer $>$

$<$ Graphic $>$

$<$ ExternalGraphic $>$

<OnlineResource xlin-

$\mathrm{k}$ :type="simple" xlink:h-

ref=" http://trac.osgeo.org/

qgis/export/15954/trunk/

qgis/images/svg/tourist/to-

urist_battlefield.svg" />

$<$ Format $>$ image /

svg $+x m l</$ Format $>$

$<$ ExternalGraphic $>$

$<$ Size $>20</$ Size $>$

$</$ Graphic $>$

$</$ PointSymbolizer $>$

This flexibility in defining map styles through parameterization of the requests is one of the many opportunities offered by services deployed within the spatial information infrastructure. This example was aimed at showing that the design of digital atlases and other products can go beyond closed solutions such as, for example, presentations in Adobe Flash - a technology that is used quite often for various publications. This use of services allows for the development of an almost infinite number of new products. The examples are systems that are currently gaining more and more popularity and are used to publish stories illustrated with the use of maps. These are called
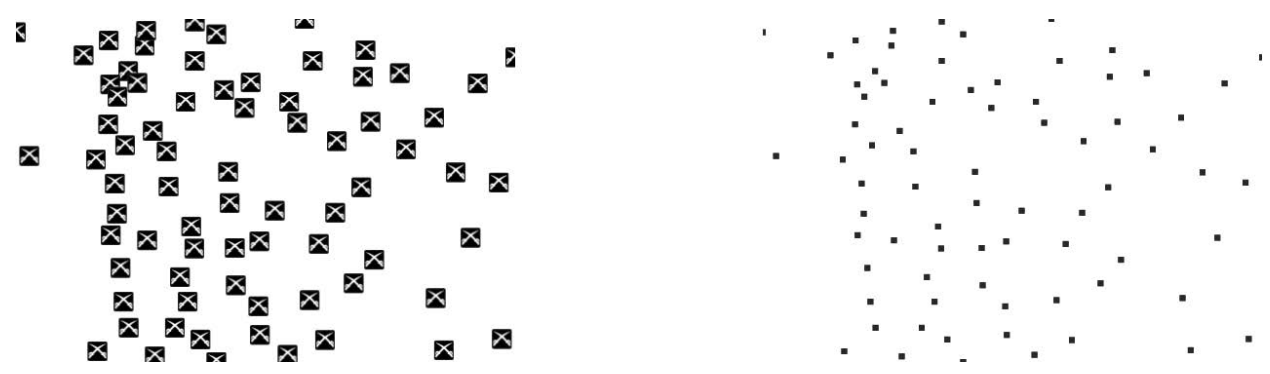

Fig. 13. Example of using different styles to visualize the same data layer (applying the style presented in the article on the left and applying the default style offered by the map service on the right).

Source: own elaboration (used software: GeoServer) 


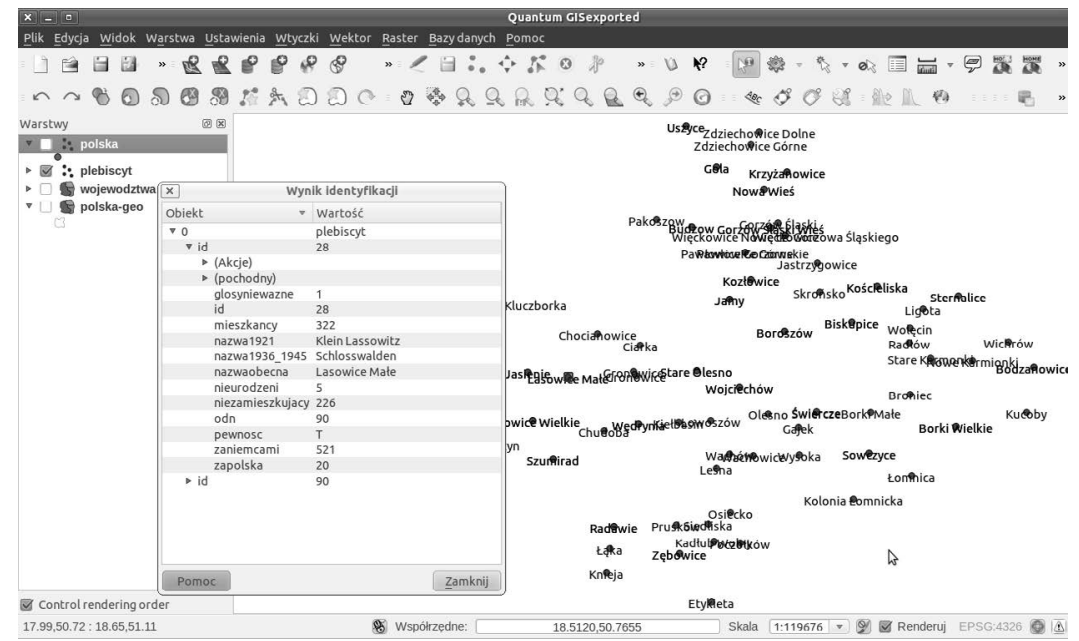

Fig. 14. Use of gazetteer services from client software (results of the 1921 plebiscite in Upper Silesia in the Olesno district (Rosenberg) as provided by own gazetteer, rendered in QGIS).

Source: own elaboration

Map Stories and can be found in commercial packages (e.g. the ESRI portfolio) as well as in open-source software packages (e.g. developed at Knight's lab, Northwestern University). They are used for education purposes, in the tourist industry and the news media.

An example of the PRNG service query (which supports the WFS - Web Feature Service, version 1.1.0 interface) with a declaration of a bounding box for the spatial extent of the data collected:

http://sdi.geoportal. gov.pl/WFSG_PRNG/service.svc/get?service $=W F-$ S\&request $=$ Get Feature\&version $=1.1 .0$ \&typename=gmgml $: \mathrm{Pol}-$ ska\&BBOX $=50.93,16.99,51$. $13,17.31 \&$ namespace $=x m l n s$ (gmgml=http: / / www . intergraph.com/geomedia/gml)

\subsection{Usage of metadata systems}

"Metadata is the term used to describe the summary information or characteristics of a set of data. This very general definition includes an almost limitless spectrum of possibilities ranging from human-generated textual description of a resource to machine-generated data that may be useful to software applications. [...] In the area of geospatial information or information with a geographic component this normally means the What, Who, Where, Why, When and How of the data" 25 .

Standardization efforts in the field of metadata for geospatial information resources that were started quite early resulted in the publication of various documents. The standardization committee of the International Cartographic Association developed and published an exact description of the national metadata profile. In 1994 the first and in 1997 the second version of the profile metadata FGDC (The Federal

\footnotetext{
${ }^{25} \mathrm{http}: / /$ gsdidocs.org/GSDIWiki/index.php?title=Chapter_3, access: 15 March 2014.
} 


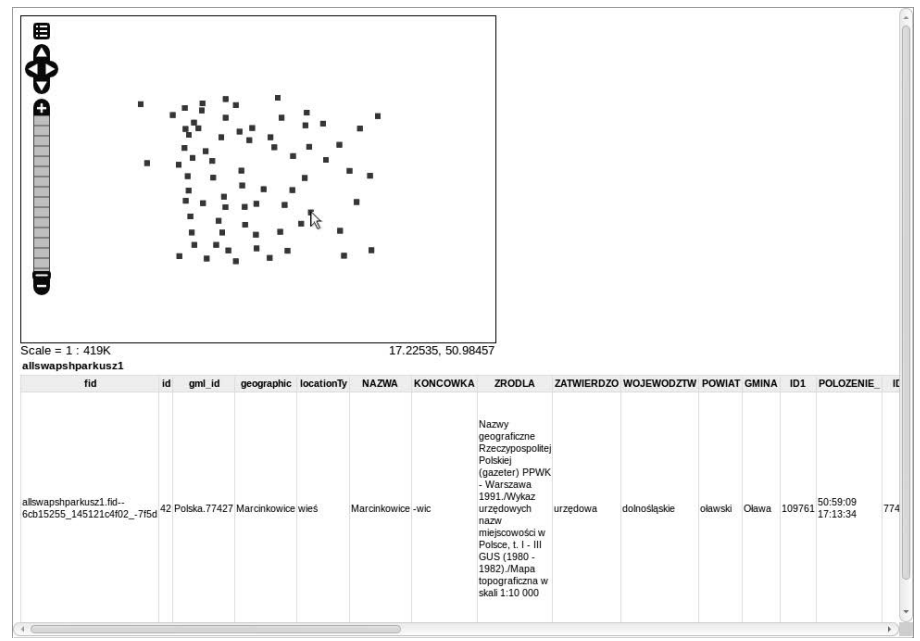

Fig. 15. Example of the visualization of data downloaded from the PRNG service (data downloaded were published as a queryable WFS layer published at GeoServer).

Source: own elaboration

Geographic Data Committee) was developed that has become the standard not only in the U.S. but also in South Africa and Australia. Another standard developed by the DCMI (Dublin Core Metadata Initiative) provides a set of standard core elements specifically for discovery metadata, i.e. for cross-domain information resource description, and includes a "coverage" element for defining the spatial location and temporal period. The most comprehensive set of geographic information-related standards comes from the ISO 19100 series. The suite of metadata standards is rich enough for describing most of the geospatial data and associated sensors and platforms. The suite of metadata standards consists of: the main standards ISO 19115, ISO 19115-2, ISO 19119, and ISO/TS 19130; and the quality standards ISO 19113, ISO 19114, and ISO 19138; and others.

From the historical resources management point of view, it is interesting how the ISO 19115 standard defines metadata elements for spatio-temporal information retrieval. As depicted in figure 16, the UML model (Unified Modeling Language) includes elements for a spatial and temporal extent description ${ }^{26}$. This model fulfills the requirements for direct and indirect spatio-temporal referencing (the spatial scheme includes enumeration with items that match the operators' names of Allen's interval algebra, see fig. 17).

While direct referencing supported by the model is exhaustive, indirect referencing is weak. The model uses a geographic identifier that refers to physical phenomena rather than describes associations among different geodetic documents. It plays a role of a key in gazetteers (fig. 18).

In the ISO 19115 a number of other metadata elements are defined, such as MD_ContentInformation and MD_Identification, that can be used to model the indirect associations. However, these metadata elements suit the general geographic domain and therefore do not meet the requirements for indirect referencing for document retrieval. These kinds of features can be supported by the use of semantic web technologies.

\subsection{Usage of the technology of Semantic Webs}

Recently, a considerable increase in interest in the semantic aspects of fan access to information can be observed. More and more often, resources are published in the global networks

\footnotetext{
${ }^{26} \mathrm{All}$ ISO UML models are available at http://www.isotc211.org/ hmmg/HTML/root.html (access: 15 March 2014).
} 


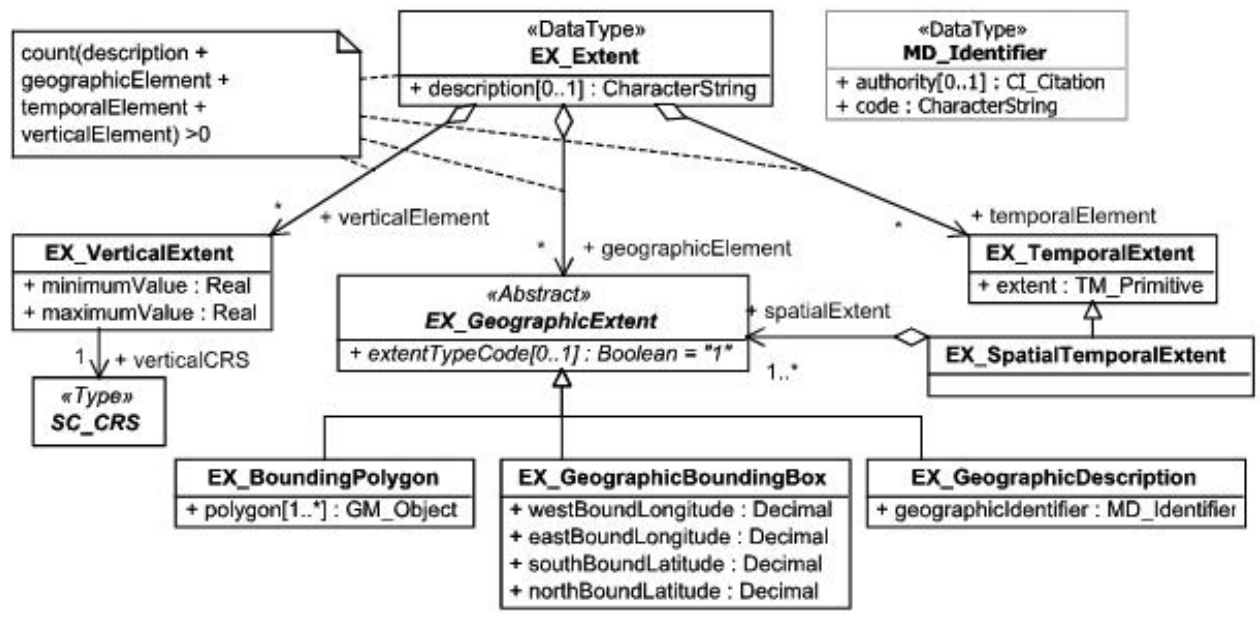

Fig. 16. UML model of extended information classes (according to ISO 19115)

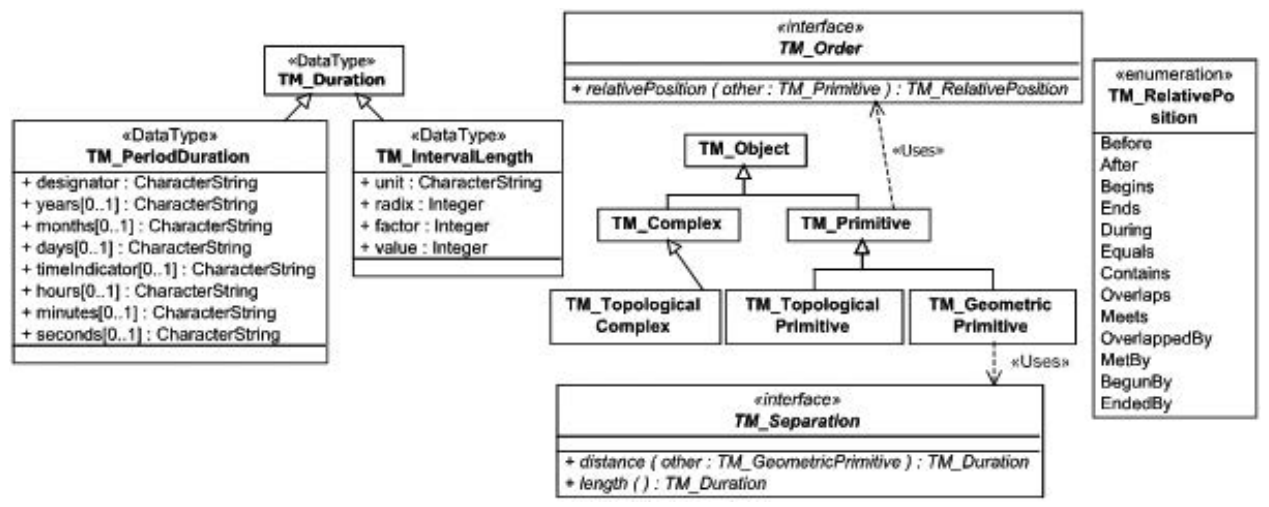

Fig. 17. UML model of temporal classes (according to ISO 19108)

of WWW and are equipped with additional information (metadata) that determines their meaning in a way that is comprehensible to computers. A global knowledge base which thus arises is called a Semantic Web, and the accompanying technologies are those of Semantic Webs.

In most cases, the creation of a semantic description is related to designing domain ontology which allows to define concepts and any of their interrelations in the structural form. Thanks to the semantic descriptions, the socalled search engines are able to independently comprehend the context that should be applied to a described resource, recognize its attributed meaning, and find the connections with other resources. This enables a more intelligent and acknowledged search, and not only ordinary word mapping. An example of an implementation in which ontology was used this way is the Elsevier Fingerprint Engine ${ }^{27}$.

The implementation and organization of digital thesauri is based on the main structur-

\footnotetext{
${ }^{27}$ https://www.elsevier.com/online-tools/research-intelligence/product -and-services/elsevier-fingerprint-engine, access: 15 March 2014.
} 


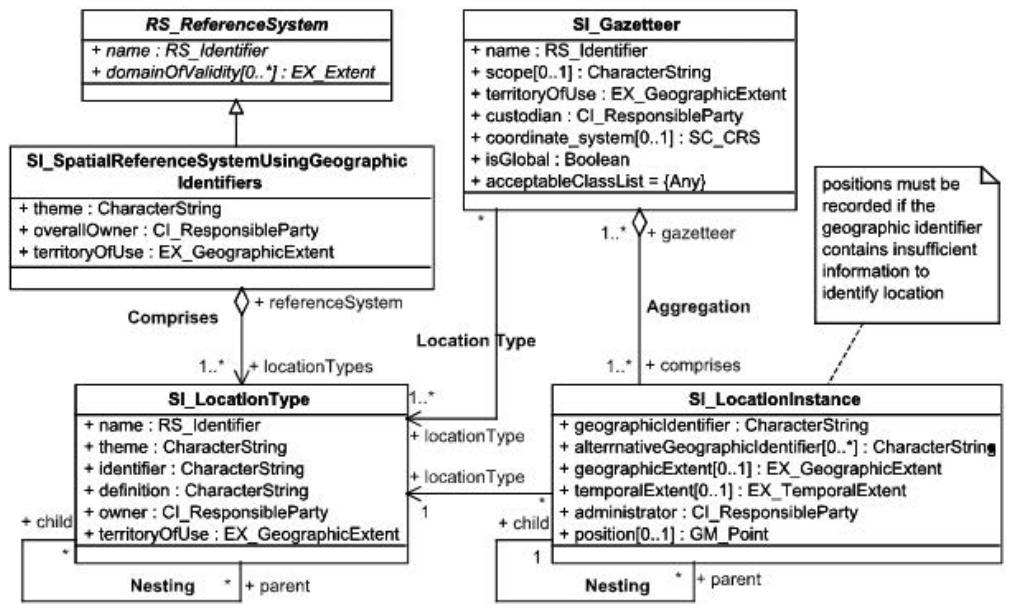

Fig. 18. UML model of classes for spatial referencing using geographic identifiers (according to ISO 19112)

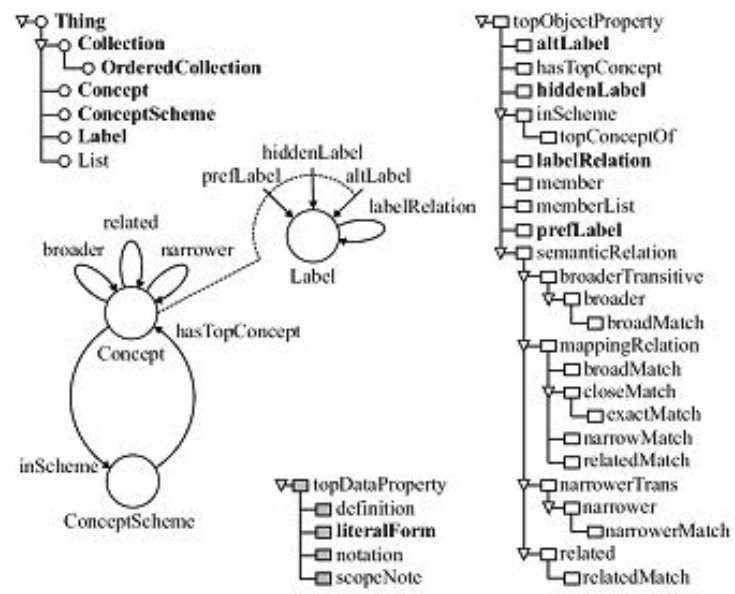

Fig. 19. Hierarchy of classes, object properties and data properties and simplified representation of the SKOS core model. Source: own elaboration

ing concepts: the terms and relations between terms: the Broader Term (BT), Narrower Term (NT) and Related Term (RT) with self-explanatory names. The main structuring concepts also incorporate terms representing other relations: Use For (UF) and its inverse Use (U) which relate to preferred terms (also known as descriptors), to non-preferred terms, and Definition (DEF) and Scope Note (SN) - used to provide a definition and additional description of a term. In general, the rule of thumb states that preferred terms should be used for indexing while non-preferred terms for searching. Only preferred terms are allowed to have the BT, NT and RT relations. If the thesauri are built on the same model, mapping between their terms exists. However, their native format, often a proprietary $\mathrm{XML}^{28}$, ASCII or relational schema, is not compatible with the Semantic Web stan-

\footnotetext{
${ }^{28}$ Extensible Markup Language (https://www.w3.org/XML/, access: 24 July 2016).
} 


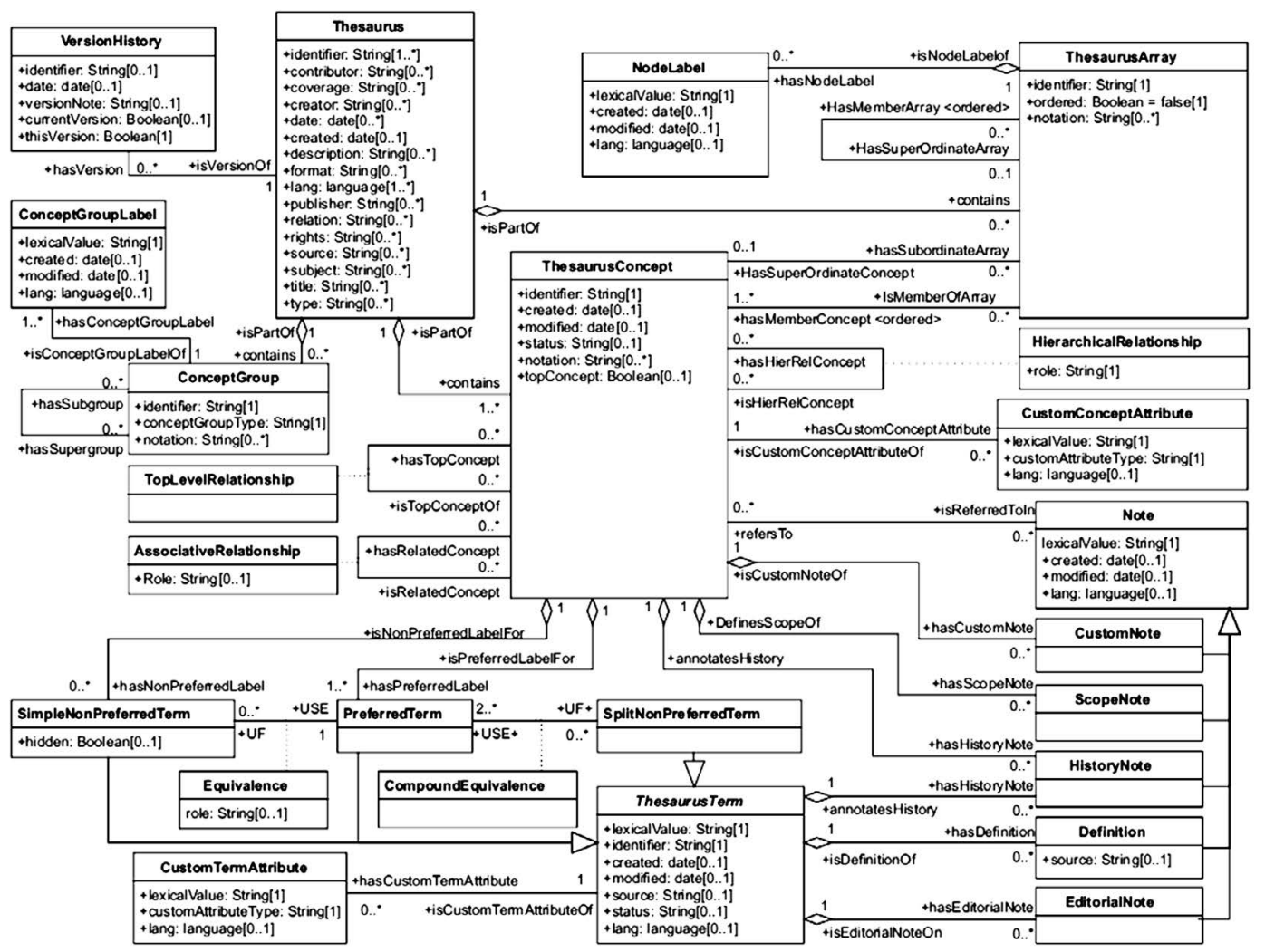

Fig. 20. UML model of thesauri as defined in ISO 25964

dard format such as $\operatorname{RDF}(S)^{29}$. The chance of cleaning up thesaurus resources is to apply the W3C SKOS ${ }^{30}$ compliant models for knowledge organization. This standard is easier to use and implement than other standards and has support from several APIs.

The SKOS data model is defined as an OWL Full ontology $y^{31}$. Although OWL Full as a data modeling language appears to be intuitively similar in many ways to other modeling approaches, such as an UML or entity-relationship model, there is an important fundamental distinction. This model is based on the open-world assumption and cannot be simply compared to

${ }^{29}$ Resource Description Framework and RDF Schema (https://www.w3.org/ RDF/, access: 24 July 2016).

${ }^{30}$ Simple Knowledge Organization System (https://www.w3.org/2004/02/ skos/, access: 24 July 2016).

${ }^{31}$ Web Ontology Language (https://www.w3.org/OWL/, access: 24 July 2016). the UML models. They are simply designed in two different conceptual domains. In figure 19, the hierarchy of SKOS classes, object properties and data properties of the SKOS core model is shown along with some relationships between the SKOS core main classes.

The construction of monolingual and multilingual thesauruses with the use of descriptors, compound terms and basic relationships was considered by the ISO. In documents published by this organization, some considerations regarding vocabulary control, indexing terms, display, and management were also presented. The data model that applies to any thesaurus aligned with this standard is presented in figure 20. This is a UML class diagram with the number of classes and attributes. Such a model can be converted to XML Schema, which can then be used for thesaurus data serialization. 
The object-oriented paradigm used here is different than the paradigm of ontological modeling. However, many of the already existing thesauri are organized according to this model (or in a similar way $)^{32}$ and for that reason it should also be considered when building systems which are the topic of this paper.

\subsection{Temporal data modeling on the part of the database}

Modeling aspects of time and space, particularly in the context of the management of historical data, is not an easy task to do. On the one hand, one has to deal with the need to remember all of the significant information that must not be lost during the transactional operations and data acquisition. On the other hand, one must aim at optimization of systems resource usage and aim to provide efficiency of the query services.

The consideration that concerns the creation and operation of specific types and structures of data that are useful in the storage of temporal data directly in the database (i.e. data that serve to represent objects and phenomena changing in time, as for example, the names of localities) were the topic of numerous publication $s^{33}$.

In data presentation usually two types of parameters of the above are distinguished - transaction time (the temporal interval in which a fact was stored in the database) and valid time (the parameter that shows when a given fact recorded in the database was, is, or will be valid for a reality being modeled). These allow to update temporal information with time without the necessity of coping with information in the database that was independent of time. This pragmatic approach is used daily by the authors of database systems and the designers of computer systems.

In computer systems, a crucial role is played by the so-called system time. Each user of a per-

${ }^{32}$ Documentation - Guidelines for the establishment and development of monolingual thesauri (ISO 2788:1986). Paperback (August 2007). Documentation - Guidelines for the Establishment and Development of Multilingual Thesauri (IS0 5964:1985=BS 6723:1985). International Standard (1985). Information and documentation - Thesauri and interoperability with other vocabularies - Part 1: Thesauri for information retrieval (ISO/ DIS 25964-1). International Standard (2010).

${ }^{33} \mathrm{~J}$. Clifford, A Model for Historical Databases, Information Systems Working Papers Series, [n.p.] 1982; C.S. Jensen, M.D. So0, R.T. Snodgrass, Unifying sonal computer or Smartphone can notice that after a hard reset of the device, which could be caused by, e.g. an exhausted battery that supports the settings of the BIOS memory, computers reset the clock to the start date of January 6, 1980 (precisely 00:00 GMT on the night of January 5th/6th, 1980), when the GPS (Global Positioning System) time started to be measured. Then measurement of time in weeks and seconds was started. GPS time is a uniform system of time measurement that is indispensable to make calculations and achieve the assumptions of the NAVSTAR-GPS system. It is maintained by the networks of an atomic clock in military and scientific bases spread throughout the world. The corrections for spacecraft clocks made in accordance with GPS time are sent online to particular satellites of the system.

The methods of time presentation in computer systems that are to transfer historical information faced the methods of defining time in historical sources. In the past, time was measured much less precisely, for example, with the particularity of years or days of the month. In different historical periods and regions, people used various calendars based on solar or lunar systems. It was not infrequent that the dates were defined relatively to the reigning rulers or to Christian holidays. The definition of data and time was often imprecise or ambiguous. This poses problems in the analysis and visualization of historical facts in contemporary computer systems.

Nowadays, there are a lot of websites (both commercial and non-commercial solutions) that provide historical maps. Next to the already mentioned service The Archive of Maps of West Poland $^{34}$, it is worth mentioning website Map Archive of Wojskowy Instytut Geograficzny 1919-1939 $9^{35}$. The website named Presentation of Old Maps Covering the Area of Czechia, Moravia and Silesia ${ }^{36}$ presents i.a. the portion

\footnotetext{
Temporal Data Models via a Conceptual Model, "Information Systems", 19, 1993, pp. 513-547; C.H. Goh, H. Lu, B.-C. Ooi, K.-L. Tan, Indexing Temporal Data Using Existing b+-trees, "Data Knowl. Eng.", 18 (2), 1996, pp. 147-165.

${ }^{34}$ http://mapy.amzp.pl/, access: 29 July 2016.

${ }^{35} \mathrm{http}: / /$ mapywig.org/, access: 29 July 2016.

${ }^{36} \mathrm{http}: / /$ oldmaps.geolab.cz/, access: 29 July 2016.
} 
material of the Military Survey of the Habsburg Empire. The portal Atlas Fontium is now an IT platform for historical research, containing presently eight topics ${ }^{37}$. The platform is the result of collaboration between researchers from Institute of History of the Polish Academy of Sciences and Institute of History of the Catholic University in Lublin. Also, do not forget about the cartographic resources of Federacja Bibliotek Cyfrowych (Digital Libraries Federation) ${ }^{38}$ and Europeana Collections ${ }^{39}$. There are also noncommercial projects offering historical maps the examples are accessible under the following URLs: http://mapy.eksploracja.pl/, http://www. posselt-landkarten.de/ (access: 29 July 2016).

\section{Conclusion}

The history of Silesia has been noted down for over one thousand years. Above all, it has been reflected in multiple compilations that involve not only descriptive elements (text) but also cartographic ones (maps). In recent decades such compilations have been published in electronic form by employing multimedia presentations which offer an array of opportunities. Products are being created in the form of electronic, interactive documents that are interconnected with audio and video streams as well as animations.

However, taking into consideration the development of information technology and computer networks, such a form of publication of findings of historical analyses is currently insufficient. All the more so since the spreading popularity of the Internet and access to web services has changed the perception and processing methods of information resources. It is more and more common to talk about network services parameterized in accordance with user demands instead of ready-made, completed products.

This trend has taken a considerable toll on the ways of publishing and exchanging information that concerns the area of public administration (an infrastructure of spatial information is being built). Nevertheless, this does not only concern publishing and exchanging information. What is crucial is the possibility of running analyses, and the construction of systems that integrate resources from various fields of science and knowledge is based on this idea.

Taking into account research on the history of Silesia, it should be considered how the existing compilations and available resources can be utilized in order to adapt to modern trends of information processing.

In our research and methodological proposal the narration is based on Silesia's past, it being a historical region in Central Europe located within Polish, Czech and German borders. Throughout the centuries it saw population exchanges (Polish, Czech, German, Jewish), changes in the faith (Catholics, Protestants, followers of Judaism), border changes and changes of state affiliation. Based on the history of a multicultural Silesia which provides numerous interesting data, we propose some methodologies of acquiring information from historical sources by means of IT tools after the process of digitalization. In consequence, due to the usage of a spatial information structure, in our considerations we go far beyond the functions offered by GIS. Thus our article is an innovative proposal in terms of using resources while employing very modern technologies.

\footnotetext{
${ }^{37} \mathrm{http}: / /$ hgisb.kul.lublin.pl/, access: 29 July 2016.

${ }^{38} \mathrm{http}: / /$ fbc.pionier.net.pl/, access: 29 July 2016.

${ }^{39} \mathrm{http}: / /$ www.europeana.eu/, access: 29 July 2016.
} 


\section{Bibliography (selected)}

Atlas historyczny Górny Ślask w XX wieku. Zbiór map edukacyjnych / Historische Atlas Oberschlesien im 20. Jahrhundert. Eine Sammlung pädagogische Landkarten, ed. M. Kordecki, D. Smolorz, cart. ed. D. Przybytek, A. Osowska, Gliwice-Opole 2013.

Borowicz D., Mapy narodowościowe Górnego Ślaska od potowy XIX wieku do II wojny światowej, Wrocław 2004.

Breslauer Urkundenbuch, Bearb. W.G. Korn, Breslau 1870.

Codex diplomaticus Silesiae, Vol. 1-36, Breslau 18571933.

Czechowicz B., Visus Silesiae. Treści i funkcje ideowe kartografii Ślaska XVI-XVIII wieku, Wroctaw 2008.

Elsevier Fingerprint Engine Home page (https:/www. elsevier.com/online-tools/research-intelligence/ products-and-services/elsevier-fingerprint-engine, access: 15 March 2014).

Gregory I.N., Ell P.S, Historical GIS. Technologies, Methodologies, and Scholarship, Cambridge 2007.

ISO UML models (http://www.isotc211.org/hmmg/ HTML/root.html, access: 15 March 2014).

Janczak J., Zarys dziejów kartografii ślaskiej do końca XVIII wieku, Opole 1976.

Kampf der Karten. Propaganda- und Geschichtskartenals politische Instrumente und Identitätstexte, Bearb. P. Haslinger, V. Oswalt, Marburg 2012.

Konias A., Kartografia historyczna państwa i zaboru pruskiego od II potowy XVIII wieku do potowy XX wieku, Słupsk 2010.

Kreft W., Przybytek D., Strauchold G., Projekt historyczno-topograficznego atlasu miast ślaskich, in: Dawna kartografia miast, Warszawa 2011, p. 465473 (Z Dziejów Kartografii, 15).

Münster S., Cosmographia. Beschreibung aller Lender durch Sebastianum Münsterum: in welcher begriffen aller Voelker, Herrschaften, Stetten, und nambafftiger Flecken, herkommen: Sitten, Gebreüch, Ordnung, Glauben, Secten und Hantierung durch die gantze Welt und fürnemlich Teütscher Nation, Basel 1544 .
Placing History. How Maps, Spatial Data and GIS Are Changing Historical Scholarship, ed. A.K. Knowles, Redlands (California) 2008.

Przybytek D., Kartografia historyczna Ślaska XVIIIXX wieku, Wrocław 2002.

Regesty śląskie, t. 1: 1343-1348, ed. K. Bobowski et. al., Wrocław 1975; t. 2: 1349-1354, ed. K. Bobowski et. al., Wrocław 1983; t. 3: 13551357, ed. J. Gilewska-Dubis, Wrocław 1990; t. 4: 1358-1359, ed. J. Gilewska-Dubis, K. Bobowski, Wrocław-Warszawa 1991; t. 5: 1360, ed. J. Gilewska-Dubis, Wrocław-Warszawa 1992.

Rozporządzenie Rady Ministrów z dnia 8 sierpnia 2000 r. w sprawie państwowego systemu odniesień przestrzennych, "Dziennik Ustaw Rzeczypospolitej Polskiej”, 70, 2000, item 821.

Schlesische Urkundenbuch, Vol. 1, Bearb. H. Appelt, Vienna-Graz-Cologne 1963.

Schlesische Urkundenbuch, Vol. 2, Bearb. W. Irgang, Vienna-Graz-Cologne 1977.

Schlesische Urkundenbuch, Vol. 3-4, Bearb. W. Irgang, Vienna-Cologne 1984-1988.

Schlesische Urkundenbuch, Vol. 5-6, Bearb. W. Irgang, Cologne-Weimar-Vienna 1993-1998.

SDI Cookbook (http://gsdidocs.org/GSDIWiki/index.php?title=Chapter_3, access: 15 March 2014).

SKOS Simple Knowledge Organization System Reference (http://www.w3.org/TR/skos-reference, access: 15 March 2014).

Skrycki R., Prace kartograficzne $w$ dolinach Odry, Warty i Noteci $w$ okresie fryderycjańskim, Szczecin 2013.

Ślask $w$ czasie i przestrzeni, ed. J. Nowosielska-Sobel, G. Strauchold, Wrocław 2009.

Towards Spatial Humanities. Historical GIS and Spatial History, ed. I.N. Gregory, A. Geddes, Bloomington (Indiana) 2014.

UMP-pcPL (http://mapa.ump.waw.pl/ump-www/, access: 15 March 2014).

Zimmermann F.A., Beyträge zur Beschreibung von Schlesien, Vol. 1-13, Brieg 1783-1796. 


\section{GIS jako narzędzie do analizy historii Śląska oraz zmian w jego geografii politycznej i kulturowej}

\section{Streszczenie}

Niniejszy artykuł dotyczy dziejów Śląska, regionu historycznego położonego w Europie Środkowej. Omówiono w nim zagadnienia związane z Systemami Informacji Geo-Historycznej (HGIS), które wykorzystują Systemy Informacji Geograficznej (GIS) w perspektywie czasowej. Termin GIS wiązany jest zwykle z narzędziami programowymi i metodami przetwarzania danych przestrzennych oraz ich wykorzystaniem w procesach decyzyjnych. Taka interpretacja podkreśla pochodzenie skrótu: systemy informacji geograficznej. W środowisku akademickim używanie jest jednak także inne, szersze pojęcie - geoinformatyka. Czy narzędzie łączące pewne aspekty geografii, nauki o Ziemi i technologii informatycznych może służyć do analiz historycznych? Istnieje wiele odpowiedzi na to pytanie, a jedna $\mathrm{z}$ nich została zaprezentowana $\mathrm{w}$ niniejszym artykule. Główny pomysł rozwiązania postawionego problemu badawczego opiera się na wykorzystaniu charakterystycznych funkcji

GIS: geokodowania i kartograficznej wizualizacji w kontekście historycznym. Zostały one przetestowane na przykładzie realizacji wybranych geoprzestrzennych usług sieciowych: mapowej i gazetera. Przystosowano je specjalnie do potrzeb analiz zmienności geopolitycznego krajobrazu Śląska. Głównym celem serwisu jest dostarczanie użytkownikowi map w danej skali, zakresie przestrzennym i czasowym oraz treści. Wdrożony prototyp serwisu mapowego wykorzystano do wizualizacji historycznych zjawisk dotyczących map Śląska. Gazeter jest słownikiem lub katalogiem terminów i nazw z odniesieniami przestrzennymi, który poprzez interfejs WWW dostarcza informacji na temat miejsc, często wzbogaconych o atrybuty opisowe. Narzędzie omówione w niniejszym artykule oferuje powiązanie historycznych nazw miejscowych Ślacka $\mathrm{z}$ ich geometrią $\mathrm{i}$ innymi parametrami zapytania użytkownika.

Keywo rds: Silesia history, Central Europe, historical maps, Historical Geographic Information System

Słowa kluczowe: historia Śląska, Europa Środkowa, mapy historyczne, Systemy Informacji Geo-Historycznej

Tomasz Babczyński, PhD - Department of Computer Engineering,

Wrocław University of Science and Technology

(e-mail: tomasz.babczynski@pwr.edu.pl)

Tomasz Kubik, PhD - Department of Computer Engineering,

Wrocław University of Science and Technology

(e-mail: tomasz.kubik@pwr.edu.pl)

Roman Ptak, PhD - Department of Computer Engineering,

Wrocław University of Science and Technology

(e-mail: roman.ptak@pwr.edu.pl)

Prof. Grzegorz Strauchold - Faculty of Historical and Pedagogical Sciences,

Historical Institute, University of Wrocław

(e-mail: strauchold@tlen.pl) 